\title{
Porphyry Cu mineralization related to the small Tertiary volcanic intrusions in the Bučim ore deposit, Eastern Macedonia
}

\author{
Todor Serafimovski', Goran Tasev', Sabina Strmić Palinkaš², Ladislav A. Palinkaš³ and Lazar Gjorgjiev'
}

${ }^{1}$ Goce Delčev University, Faculty of Natural and Technnical Sciences, Krste Misirkov bb, PO. Box 201, MK-2000 Štip, Republic of Macedonia (goran.tasev@ugd.edu.mk; todor.serafimovski@ugd.edu.mk)

${ }^{2}$ University of Tromsø, Faculty of Science and Technology, Department of Geology, Dramsvegen 201, N-9037 Tromsø, Norway, (sabina.s.palinkas@uit.no) ${ }^{3}$ University of Zagreb, Faculty of Science, Department of Geology, Institute of Mineralogy and Petrology, Horvatovac 95, HR-10000 Zagreb, Croatia (lpalinkas@gfz.hr)

101-119 12 Figs. 8 Tabs.

doi:10.4154/gc.2016.09

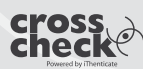

Article history:

Received September 14, 2015

Revised and accepted January 05, 2016

Avaliable online February 29, 2016
Keywords: Bučim, ore deposit, porphyry, Republic of Macedonia

\begin{abstract}
The paper presents data about the geology, geochemistry, structure, genesis and specific features of the Bučim porphyry $\mathrm{Cu}$ deposit which is actively mined in Macedonia. The porphyry mineralization $(0.3 \% \mathrm{Cu}, 0.3-0.5 \mathrm{ppm} \mathrm{Au})$ is spatially and temporarily associated with Tertiary subvolcanic intrusions of latitic and latitic-andesitic composition. The intrusions occurred during Oligo-Miocene time (24 to $27 \mathrm{Ma}$ ), a period of intensive tectono-magmatic and ore-forming processes..

The latest results of this study identify an array of major ore (hypogen) minerals such chalcopyrite, pyrite, magnetite, haematite, cubanite, valleriite, native $\mathrm{Au}$ and bornite and secondary enrichment zone minerals (within Čukar ore body) including chalcocite, covellite, tenorite, native $\mathrm{Cu}$, malachite, azurite etc. Added minerals such as calaverite, krennerite, electrum, petzite and bismuth \pm selenium minerals (bismuthinite, galenobismutite, krupkaite, friedrichite, emplectite, cosalite, laitakarite and native bismuth) are also present. Variations of the $\delta^{34} \mathrm{~S}$ values for the whole Bučim ore deposit ranged from $+0.2 \%$ to $+2.5 \%$ while $\delta^{13} \mathrm{C} \%$ and $\delta^{18} \mathrm{O} \%$ isotope values ranged from -10.8 to $-3.8 \%$ and from +14.0 to $+22.7 \%$, respectively. With regard to fluid inclusions, it was confirmed that beside the pre-dominant gas-liquid, two-phase inclusions, there are also three-phase fluid inclusions (gas + liquid + solid phase). Also, recent $\mathrm{Sr}$ and $\mathrm{Nd}$ isotope ratios $\left({ }^{87} \mathrm{Sr} /{ }^{86} \mathrm{Sr} 0.70666-0.70741\right.$ and ${ }^{143} \mathrm{Nd} /{ }^{144} \mathrm{Nd}$ $0.512487-0.512489$ ) indicate slight contamination of the magmatic products by continental crust material, due to partial melting of the deep parts of continental crust underthrust by collision of continental blocks. The REE data show results that are comparable with high contents of large ion lithophile elements (LILE), high $\mathrm{Ba} / \mathrm{Nb}$ ratio (116.72-190.72) and depletion in high field strength elements (HFSE) and Europium negative anomaly (0.68893-0.91251).
\end{abstract}

\section{INTRODUCTION}

The Bučim porphyry $\mathrm{Cu}$ deposit is located in the border area between the Serbo-Macedonian Massif (SMM) and the Vardar Zone (VZ). It is an integral part of the Bučim-Damjan-Borov Dol ore district located in the eastern part of the Republic of Macedonia. In terms of its metallogeny, it belongs to the Lece - Chalkidi metallogenic zone (SERAFIMOVSKI, 1990), which is a part of the Alpine-Balkan-Carpathian-Dinarides metallogenetic belt (HEINRICH \& NEUBAUER, 2002). The intrusions of the district belong to the Late Eocene-Oligocene magmatic zone (HARKOVSKA et al., 1989), which cross cuts older tectonic structures (SCHEFER et al., 2011), and occurs within the Circum Rhodope unit according to the compilation map of SCHMID et al. (2013). The Late Oligocene-Miocene intrusions are associated with both economic and uneconomic ore mineralization. Although the mine at Bučim has been known since ancient times, it was not explored in detail until the 1970's (SERAFIMOVSKI et al., 2010).

In terms of its output and ore reserves, it is a small porhyry deposit. Since 1979, $80 \mathrm{Mt}$ of the $120 \mathrm{Mt}$ estimated reserves (as mineral resources), have been mined, with a production dynamic of 4000000 tonnes ore annually and an average ore grade of $0.34 \% \mathrm{Cu}$ and $0.35 \mathrm{~g} / \mathrm{t} \mathrm{Au}$ (ČIFLIGANEC, 1993;
SERAFIMOVSKI et al., 1996, 2010; VOLKOV et al., 2010). It should also be mentioned that this is characteristic of all porphyry deposits determined in the border area between the SMM and the VZ or the Lece - Chalkidi zone. The deposit consists of four ore bodies, three of which are related to porphyry fingers and one is distinguished as a supergene mineralization (ČIFLIGANEC, 1993; SERAFIMOVSKI \& BOEV, 1996; SERAFIMOVSKI et al., 2010; VOLKOV et al., 2010). The intrusions are of andesitic to trachy-andesitic composition with crystallization ages ranging between 27.5 and $24.9 \mathrm{Ma}$ (K/Ar whole rock ages) (ČIFLIGANEC, 1993; SERAFIMOVSKI et al., 2010).

Various mineralogical and fluid inclusion studies have been undertaken in the district but only a limited amount of data related to the magmatic-hydrothermal history of the system have been published (ČIFLIGANEC, 1993; SERAFIMOVSKI \& BOEV, 1996; SERAFIMOVSKI et al., 2010; STRASHIMIROV et al., 1996; VOLKOV et al., 2010).

\section{REGIONAL GEOTECTONIC AND METALLOGENIC SETTING}

The metallogeny of the southern Balkan Peninsula is determined by the geodynamic evolution of the Tethys-Eurasian 


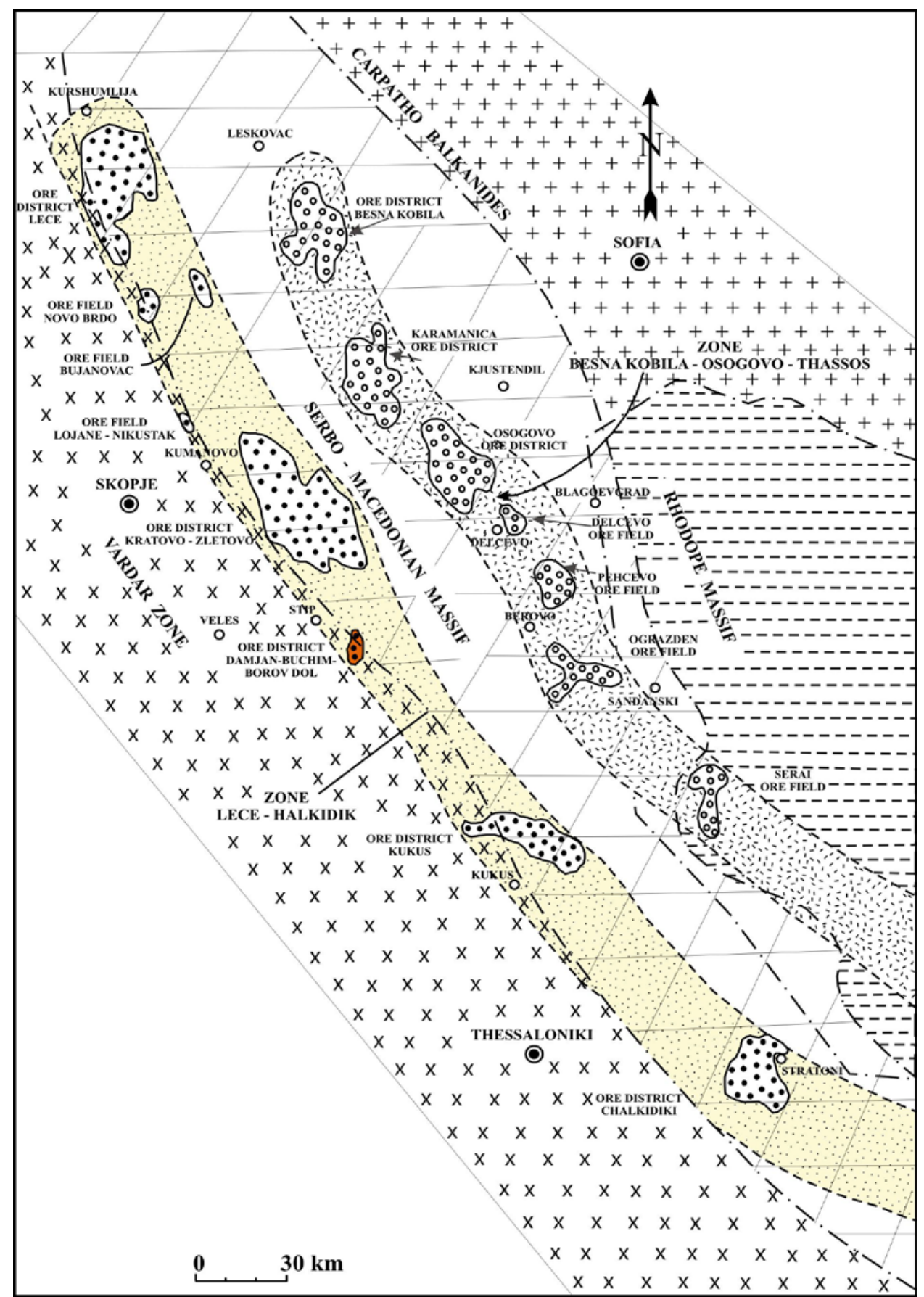

Figure 1. Regional location of the Lece-Chalkidiki and Besna Kobila-Osogovo-Thassos metallogenic zones and area of interest (modified after SERAFIMOVSKI, 1990).

metallogenic belt (TEMB), as outlined by JANKOVIĆ (1997), and ancient crystalline massifs. The TEMB formed during post-Mesozoic times in the location of the former Jurassic Tethys palaeo-ocean, situated between the southern continental margin of Eurasia on one side, and the African-Arabian and Indian plate on the other side. The belt extends from the western Mediterranean, through the Alps and southeastern Europe via the Lesser Caucasus, Hindu Kush, and Tibetan Plateau, to Burma and northwestern Indonesia, where it joins the western segment of the Pacific metallogenic belt. The southern Balkan Peninsula, including the Republic of Macedonia, is a sector of the central TEMB (Fig. 1).
The formation of ore deposits was related to certain chronological stages and geodynamic settings: (1) Late Permian-Early Triassic intracontinental rifting along the northern boundary of Gondwana and/or its previously detached fragments; (2) Jurassic oceanization marked by the ophiolitic complex; (3) suprasubduction magmatism; and (4) a postcollisional (orogenic) continental setting and related formation of various baseand noble-metal deposits ( $\mathrm{Pb}-\mathrm{Zn}$ $\mathrm{Ag}, \mathrm{Cu}-\mathrm{Au}, \mathrm{Au}-\mathrm{As}-\mathrm{Sb}-\mathrm{TI}, \mathrm{Au}-\mathrm{Ag}$ ) (JANKOVIĆ, 1997). The Jurassic ophiolite belt extends for hundreds of kilometres within Macedonia and for a few thousand kilometres on a global scale via Greece, Turkey, the Caucasus, and Iran to the Himalayas. In Macedonia, the ophiolite complex occurs in the Vardar Zone (VZ) and the adjacent Serbo-Macedonian Massif (SMM) (KARAMATA \& LOVRIĆ, 1978). The VZ extends in a NW-SE direction between the SMM and the Pelagonian Massif (Fig. 1). Ophiolites of the VZ comprise the Jurassic gabbro-peridotite complex, which is overlain by Cretaceous flysch. The SMM is located between the Carpathian Mountains and the Balkanides in the east and the VZ in the west. Dismembered peridotites in the form of pseudodykes occur in the SMM along its contact with the VZ. The collision of the African and Eurasian plates was accompanied by closure of the ocean and subduction of the oceanic crust beneath the SMM. Deep faults that formed along the active continental margins have important metallogenic implications. The regional tectonic units listed above, extending parallel to the VZ, control regional metallogenic zones, ore districts, and ore fields (Fig. 1). Collision, post-collision processes, and Tertiary magmatism were crucial for localization of the base-metal ore mineralization (JANKOVIĆ, 1997; SERAFIMOVSKI et al., 2010).

Cenozoic reactivation embraced largely the eastern part of the Macedonian Arch and was expressed in the development of the NW-trending faults oriented obliquely to the $\mathrm{VZ}$ and the transverse NE-trending faults at the final stage (TOMSON et al., 1998; VOLKOV et al., 2006). The rocks of the Tertiary volcanic-plutonic complex and related base-metal mineralization occur in four tectonic and metallogenic zones (Fig. 1): (1) 
the magmatic zone at the mobile northern, northeastern, and eastern margins of the Dinarides (Mala Kropa, Srebrenica, Boranja, Golija, Zeljin, Rogozna; PAMIĆ \& JURKOVIĆ, 1997; JANKOVIĆ, 1997); (2) the magmatic zone in the severely tectonized central part of the VZ (Kopaonik, Bukulja, Avala, Cer, Kožuf; JANKOVIĆ, 1997; JANKOVIĆ et al., 1997); (3) the Lece-Chalkidiki metallogenic zone at the contact between SMM and VZ (Zletovo, Plavica, Bučim, Borov Dol, Damjan, Borović; SERAFIMOVSKI, 1993; SERAFIMOVSKI et al., 2000); (4) the Besna Kobila-Osogovo metallogenic zone (Sasa, Toranica, Kadica, Ilovica; SERAFIMOVSKI, 1990).

The Precambrian metamorphic complex is the oldest in the SMM (Fig. 1). The complex is composed of biotite, muscovite, (two-mica), and gneisses, amphibolites, muscovite schists, and other kind of metamorphic rocks. Gneisses are widespread and favourable for the localization of ore. Palaeozoic rocks comprise chlorite-amphibole schists, slate-carbonate group, metagabbro, and dolerite, which are less favourable for the localization of porphyry ore than the Precambrian rocks. The Mesozoic formations combine Jurassic ultramafic and granitic rocks. Serpentinized peridotites and pyroxenites are locally overlapped by volcanic flows and Quaternary sediments. Granite, granodiorite, and quartz monzonite are accompanied by low-grade chalcopyrite mineralization. Palaeogene sedimentary rocks (conglomerate, tuffaceous flysch, limestone) are cut through by Neogene subvolcanic intrusive bodies. These rocks, especially marlstone and shale, are favourable hosts for porphyry and skarn mineralization; they serve as screens for ore-bearing fluids and protoliths for metasomatic alteration. Neogene conglomerate, gravelstone, sandstone, limestone, and other sedimentary rocks are overlapped by Quaternary clayey and sandy sediments (fans, hillside, and alluvial facies) (e.g. DUMURDŽANOV et al., 2004).

Three variably oriented fault systems are recognized: the first NW-trending fault system coincides in the strike of the major tectonic units; while the second and third systems extend in the northeastern and meridional directions, respectively. The third system has important implications for the development of Tertiary magmatism and related iron skarn and porphyry $\mathrm{Cu}$ mineralization. This system controls numerous volcanic domes and necks localized at intersections of nearmeridional and northeastern faults. Volcanic activity progressed from the beginning of the late Oligocene, and ore mineralization formed in Miocene times (SERAFIMOVSKI et al., 2010).

\section{BUČIM-DAMJAN-BOROV DOL ORE DISTRICT}

The Bučim-Damjan-Borov Dol ore district with porphyry $\mathrm{Cu}$ and iron skarn mineralization occupies the southwestern part of the Lece-Chalkidiki metallogenic zone and is about $50 \mathrm{~km}^{2}$ in size. The ore mineralization is concentrated in the Bučim, Damjan, and Borov Dol ore fields (Fig. 2). Several NW-SE striking thrust faults divide the district into different tectonic units (Fig. 2, see HRISTOV et al., 1973).

The aforementioned thrust faults are related to Early Miocene crustal shortening, which led to about $800 \mathrm{~m}$ of uplift of the Bučim region in the Borov Dol area, which in turn is uplifted $800 \mathrm{~m}$ relative to the area located to its west (based on field observations, there are different exposure levels between Bučim and Borov Dol, Fig. 2B). The preservation of Eocene strata decreases towards the NE due to erosion. Therefore, deeper geological units, such as Palaeozoic schists and Precambrian gneisses, are increasingly exposed towards the NE (Fig. 2). Numerous intrusions are found in the area, among them the Bučim, Damjan, Borov Dol and Black Hill intrusions. After the emplacement of the porphyry intrusions, a later period of thrust faulting led to uplift of the Bučim area in contrast to the Borov Dol-Damjan region (Figs. 1, 2, 3). Several andesite/trachyandesite intrusions, which are embedded in the volcanic tuffs, host the Borov Dol $\mathrm{Cu}$ mineralization (ČIFLIGANEC, 1993; SERAFIMOVSKI et al., 2010), which offers a view into a shallow magma chamber. It is located $8 \mathrm{~km}$ SSW of Bučim also in the Circum Rhodope belt. ČIFLIGANEC (1993) dated the Bučim andesites by K-Ar whole rock methods and they yielded ages between 27.5 and 24.9 Ma and the Damjan and Borov Dol andesites range in age from 28 to 26.5 Ma. The faults in the area mostly trend NNW-SSE and NNESSW, and the distribution of the intrusions largely follows them (SERAFIMOVSKI \& BOEV, 1996).

The Bučim ore field is localized in the northern part of the ore district within the SMM and is characterized by (1) NWand NE-trending low-order faults; (2) prevalence of latite and trachy-latite dykes and minor intrusions as products of Tertiary volcanism; and (3) porphyry $\mathrm{Cu}$ mineralization. No volcanic domes or calderas expressed as landforms are known. Only small ring structures, a few hundreds of metres - $1.5 \mathrm{~km}$ in diameter accompanied emplacement of the subvolcanic stocks. The outer parts of such structural forms are composed of gneiss, whereas the inner parts are composed of latitic stocks. Similar structural forms are widespread elsewhere in this ore district. In addition to the Bučim deposit, numerous porphyry $\mathrm{Cu}$-occurrences are known in the north of the district (Vranjak, Crn-Vrv-Kalapetrivci etc.).

The Damjan ore field is localized in the southeastern part of the ore district at the contact between the Damjan horst and the Vardar Zone and is characterized by (1) NW-SE, NNWSSE, NE-SW striking fault structures; (2) prevalence of Jurassic ultrabasics, Palaeogene flysch sediments, Tertiary volcanics and newly formed metasomatic products, skarns; and (3) Fe-skarn mineralization. The intrusions are of variable size and created diverse host rocks of different tectonic units. The Damjan Fe-skarn deposit is located about $4 \mathrm{~km}$ south of Bučim and is one of the rare skarn deposits, which formed at the contact between the andesite and Palaeogene flysch. Mineralization itself is hosted by skarns and is represented by rich magnetite-haematite parts $(>40 \% \mathrm{Fe})$.

The Borov Dol ore field is localized at the margin of a volcanic caldera in the southern part of the ore district within the VZ. The caldera, $5 \mathrm{~km}$ in diameter, is clearly expressed in topography and complicated by several volcanic domes and depressions $1.0-1.5 \mathrm{~km}$ in diameter. One of these depressions hosts the Borov Dol deposit. The NW-trending faults control the Neogene latite and quartz latite dykes, necks, and extrusions. The Borov Dol deposit is related to this volcanic-plutonic complex. The ore-bearing volcanic rocks are metasomatically altered. The volcanic rocks belong to the high-K shoshonitic series and correspond to monzodiorite and monzonite 


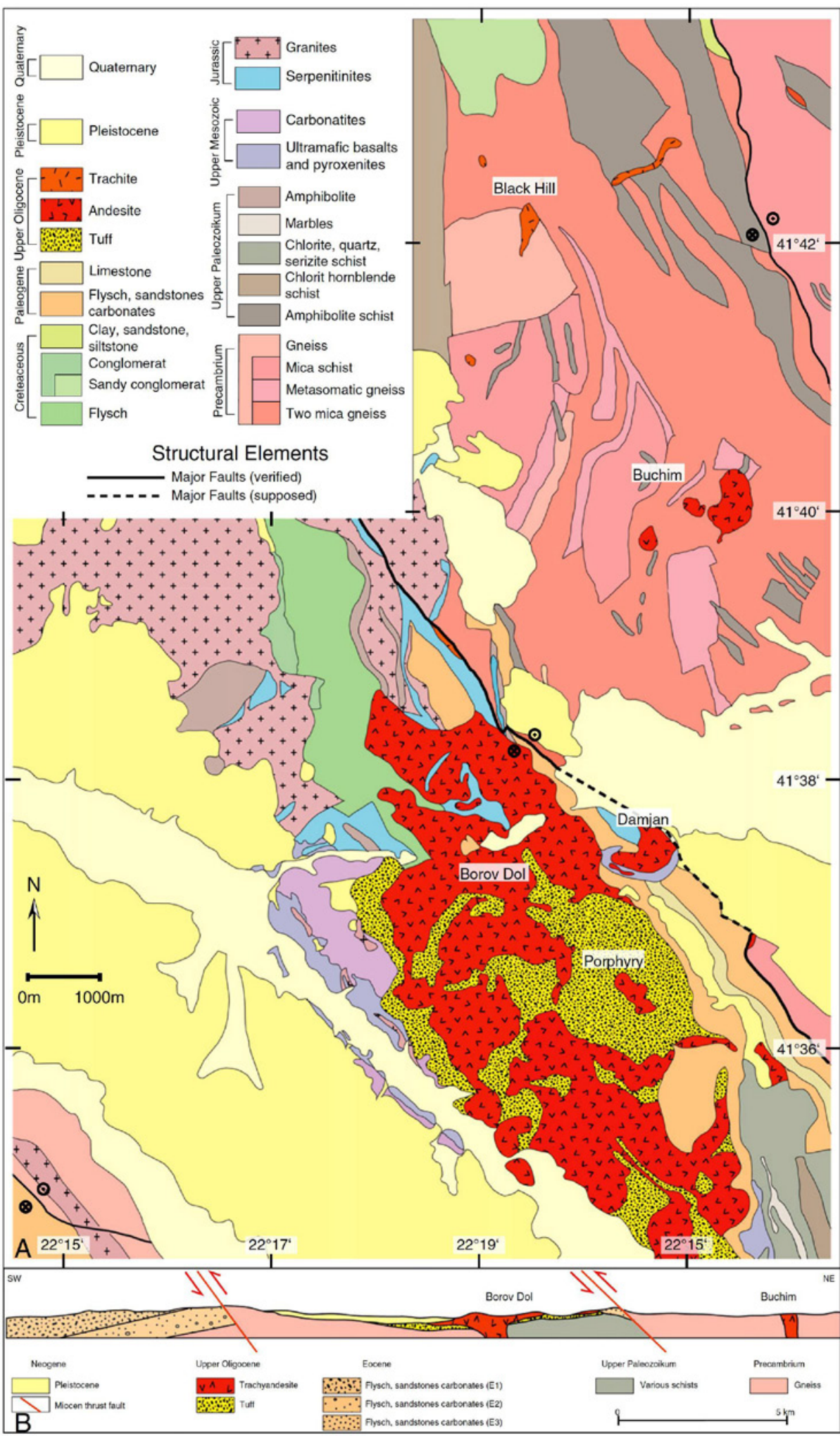

Figure 2. A: Geological map of the Bučim-Damjan-Borov Dol ore district, modified after an unpublished mine map of HRISTOV et al. (1973); B: Schematic cross section through the BučimDamjan-Borov Dol ore district (modified by LEHMANN et al., 2013).

in $\mathrm{K}_{2} \mathrm{O}-\mathrm{SiO}_{2}$ discrimination. These are andesite, latite, trachyte, and rhyolite, including transitional varieties (SERAFIMOVSKI et al., 2010; LEHMANN et al., 2013). It is worth mentioning that the rocks of the shoshonitic series are typical of districts with porphyry $\mathrm{Cu}$ mineralization at continental margins, e.g., Bajo Alumbrera, Gunumba, Bingham, Ok-Tedi, Grasberg, Cadia, etc. (MÜLLER \& GROVES, 2000; BLEVIN, 2002).

\subsection{GENERAL FEATURES}

As previously mentioned the Bučim deposit, located in the northeast of the ore district (Fig. 2), has been recognised since ancient times, but was only explored in detail in the 1970s. About $80 \mathrm{Mt}$ of ore have been extracted, with an average grade of $0.34 \% \mathrm{Cu}$ and $0.35 \mathrm{~g} / \mathrm{t} \mathrm{Au}$, from the $120 \mathrm{Mt}$ ore reserves, as determined in 1979. The annual exploitation capability of the mine is $4 \mathrm{Mt}$ of ore. At present, ore with $0.21 \% \mathrm{Cu}, 0.2 \mathrm{~g} / \mathrm{t}$ $\mathrm{Au}$, and $0.8 \mathrm{~g} / \mathrm{t} \mathrm{Ag}$ is being mined. About 32000 t of concentrate containing 18-21\% $\mathrm{Cu}$ and $18 \mathrm{~g} / \mathrm{t} \mathrm{Au}$ (Au recovery is 50\%) has been produced and delivered by trucks to smelters at Bor in Serbia and Pirdop in Bulgaria. At the moment, the Bučim Mine is owned by the Solway Investment Group Limited.

The Bučim deposit is likely the world's smallest deposit of this type currently operated as a mine. The successful mining of this deposit for many years refutes the popular opinion that the porphyry $\mathrm{Cu}$ deposits profitable for mining must contain no less than $2.5 \mathrm{Mt}$ of $\mathrm{Cu}$ metal and the $\mathrm{Cu}$ grade in ore should be higher than $0.5 \%$ (SERAFIMOVSKI et al., 2010).

\subsection{GEOLOGY OF THE DEPOSIT}

The first written data about the geological setting of the Bučim area can be found in the works of CVIJIĆ (1906, 1924) followed by publications by BONČEV (1920), PETUNIKOV (1940, 1944), PAVLOVIĆ (1939) and others. The geological setting of the immediate surroundings of the deposit includes the following end members:

\subsubsection{Precambrian metamorphic complex}

This is the most domimant geological unit in the area and is represented by its heterogenous lithological composition. Such a lithological heterogenity resulted from the fact that the primary accumulation of sedimentary and magmatic rocks was subjected to regional metamorphism as well as to later retrograde processes, the influence of Precambrian granitoid magmatism and 
Jurassic granitoid magmatism associated with a progressive Abakuma type of metamorphism and finally the influence of hydrothermal processes related to the Tertiary magmatism (PETKOVIĆ, 1966; PETKOVIĆ et al, 1968; DUMURDŽANOV et al., 1969; CULEV et al., 1970).

Gneisses are the most widespread rocks in both the broader and immediate areas around the deposit. According to their mineral composition, several facies can be discriminated (which mutually replace each other): biotite gneisses, amphibole-biotite gneisses, muscovite gneisses, two-mica gneisses, and metasomatic (leucocratic) gneisses. During the exploitation of the Central Part of the ore body, the variability in chemical composition of the gneisses was determined more accurately. They consist of bands of mica (biotite and muscovite) alternating with quartz bands. Garnet occurs as the dominant mineral besides quartz, biotite and muscovite. Apatite is an accessory mineral. Mica-schists represent a normal lithological member of the crystalline schists in which they occur as an interstratified facies. Consequently, they are of the same metamorphic age. From the aspect of mineralization, they represent an unfavourable environment, compared with the gneisses, being poorly permeable for hydrothermal solutions. Amphibolites occur in the crystalline schists in the form of lenses or strata and larger irregular masses. Generally, they are concordant to the crystalline schists and at places depart from their foliation. They are characterized by their dark green colour and shaly texture.

\subsubsection{Palaeozoic magmatic rocks}

They occur in the form of small lenses distributed along clearly pronounced ruptures. So far, the following have been recog-
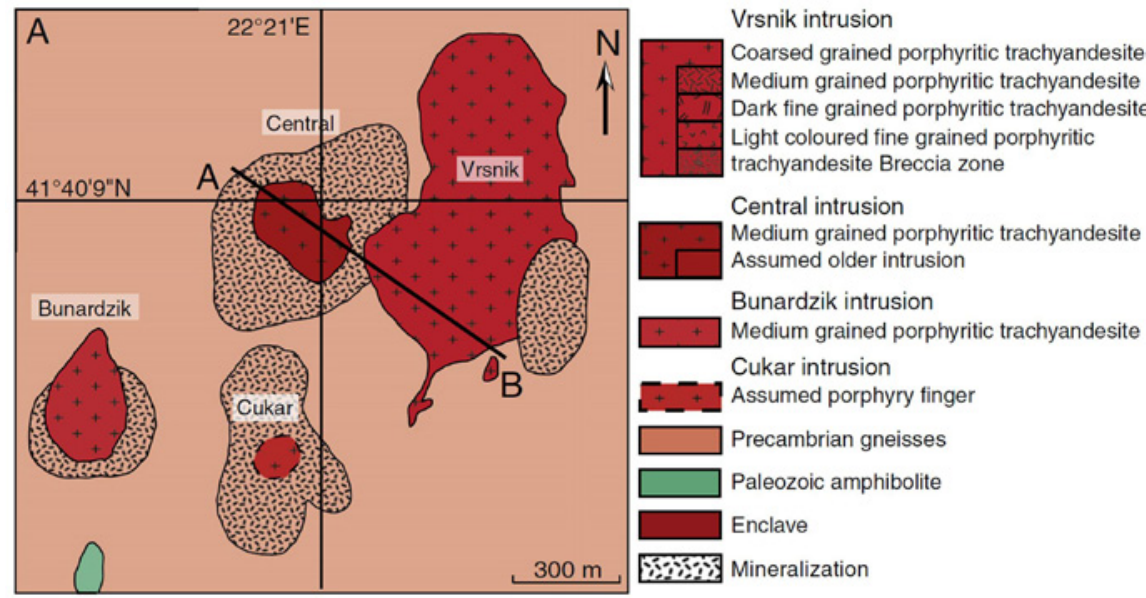

700 N.N.

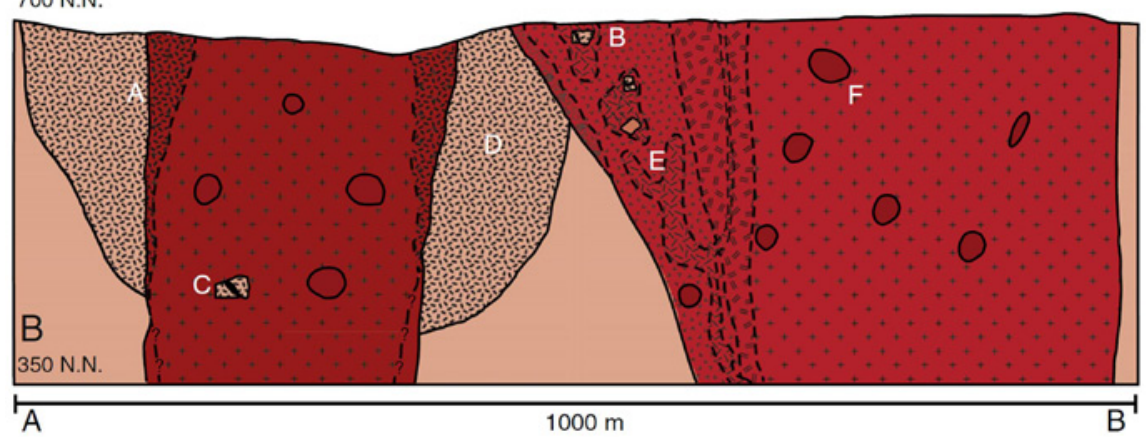

Figure 3. Geological scheme and cross section through the Bučim ore deposit (SERAFIMOVSKI \& BOEV, 1996). nized (CULEV, 1970): Amphibolites, fine-grained rocks of a thin banded texture, which represent an unfavourable environment for deposition of the $\mathrm{Cu}$ mineralization. They are composed of hornblende, plagioclase, and partly, foliated biotite and chlorite aggregates (IVANOV, 1982; ČIFLIGANEC et al., 1993). Serpentinites occur north of the Vršnik orebody. They have significant size and thickness (about $10 \mathrm{~m}$ ), and are distributed along the rupture zone. Serpentinites, although grouped into the Palaeozoic age, are more probably of Jurassic age and represent the remaining parts of the Vardar-lzmir Ocean. Their position along the rim of the Serbo-Macedonian massif can be explained by diapiric and/or tectonic intrusion. Such serpentinite dykes (in the form of stratified series, sometimes even subparallel) occur in the vicinity of porphyry deposits at Chalkidiki, Greece (SERAFIMOVSKI, 1990). Finegrained to porphyroid gabbros are very compact, dark green to black. Their structure suggests their veined character and peripherial position within the intrusive massif.

\subsubsection{Tertiary volcanic rocks}

Tertiary magmatic rocks played an important role in the geological setting of the Bučim deposit (MAJER, 1958; KARAMATA 1983; ČIFLIGANEC, 1987, 1993; DENKOVSKI et al., 1983; DENKOVSKI \& BANDILOV, 1985; SERAFIMOVSKI 1990; 1993; STOJANOV \& SERAFIMOVSKI, 1990; STOJANOV \& BOEV, 1993; BOEV \& YANEV, 2001). They occur as minor intrusives within the Precambrian metamorphic complex. During the Neogene, tectonic and magmatic processes resulted in widespread magmatism. At the present erosion level it is represented by sub-volcanic and volcanic facies of latite and andesite in the form of dykes and necks. In the intrusive level the rocks range in composition from quartz diorite to granodiorite. In terms of chemistry, they belong to calk-alkaline and alkaline affinity. At later stages, they were enriched in potassium.

The ore deposition is genetically connected to the emplacement of Tertiary, Oligocene-Miocene subvolcanic latitic and latite-andesitic bodies within Precambrian metamorphic rocks-gneisses, micashists, and amphibolites (27.5-24.5 m.y., SERAFIMOVSKI, 1993, or 24.524.0 m.y., LEHMANN et al., 2013).

\subsection{ORE MINERALIZATION}

The Bučim deposit is composed of a magmatic complex consisting of three proven finger-like porphyry stocks (Central Part, Vršnik and Bunardžik) while the Čukar ore body, a supergene mineralization developed in gneiss, has already been mined out (ČIFLIGANEC, 1993, Figure 3).

The morphology of the Čukar orebody was closely related to the structural-textural features which controlled penetration of the descedent solution responsible 
for supergene processes on the primary ore mineralization. The shape of the orebody resembles a lense striking northsouth, while the thickness of the supergene sulfide ore-bearing zone does not exceed $60 \mathrm{~m}$ (the absolute height of the supergene mineralization was between 645-505 $\mathrm{m}$ a.s.1.). The length and width of the ore body were 400 and $200 \mathrm{~m}$, respectively. According to new geological field observations a magmatic stock is assumed to sit below the Čukar ore body (personal communication with local mining geologists; Figure 3A). Unfortunately, drill cores are now unavailable and the pile of waste from the open pit has accumulated on the remains of the body.

The mineralization of the Central ore body porphyry is cut by the Vršnik intrusion. This relationship is visible in mineralized gneiss clasts, which contain veins that are cut off by the magmatic intrusion. Accordingly, the Central intrusion is older than the Vršnik intrusion (Figure 3B). The Central Part ore body is emplaced in various Precambrian gneisses of the Circum-Rhodope unit.

The morphology of the ore body, conformable with the intrusion (stock) almost isometrically on plane, resembles reverse or truncated cones emplaced mutually into each other (with a diameter of $500 \mathrm{~m}$, surrounding an andesitic stock with a vertical depth of more than $500 \mathrm{~m}$, see Fig. 3B). The interior cone has smaller angles of overlap of the conical surfaces, while the outer cone, in relation to the andesite intrusion, is more inclined. The $\mathrm{Cu}$ mineralization is primary (hypogene). The most significant ore mineral is chalcopyrite, which is accompanied by pyrite, magnetite, haematite, cubanite, valerite, native $\mathrm{Au}$, bornite and others (SERAFIMOVSKI \& BOEV, 1996). Gneiss xenolithes in the magmatic stock contain pyrite in veinlets, which are cut through by the magmatic intrusion. Therefore, the present magmatic rock overprints an earlier magmatic and hydrothermal event.

The Bunardžik ore body (Fig. 3) shows the same mineralization as the Central Part ore body, but the ore-minerals are scarcer (ČIFLIGANEC, 1993). The mineralization of the Bunardžik ore body is hosted by Precambrian gneisses. In contrast to the Central ore body, however, the Bunardžik ore body is crescent shaped adjacent to the andesitic intrusion and far from being symmetrical in relation to the andesite intrusion. The angles of dip of the outer surfaces outlining the orebody are smaller than the angles of the dip of the contact andesite intrusion. The andesite intrusion, also non-mineralized, is situated outside the orebody (Figure 3). The morphology of the Bunardžik orebody is mostly affected by the position of the andesite intrusion. On plane, the Bunardžik orebody resembles a horse-shoe positioned around the southern part of the andesite intrusion emplaced in gneiss. The dimensions of the body are $300 \times 100 \mathrm{~m}$ at the surface with a $300 \mathrm{~m}$ depth (ČIFLIGANEC, 1993).

The Vršnik ore body (Figure 3), which is located east of the Central ore body, is ellipsoidal in shape. In contrast to the afore-mentioned bodies, emplaced into gneiss, the Vršnik orebody features mineralization chiefly hosted by the intrusions (andesite) and partly by the gneiss (Figure 3). In certain places, this is a single unique orebody, while elsewhere two parts can be distinguished. This orebody stretches over an interval of about $80 \mathrm{~m}$ (at the absolute height of 680-600 m). Its longer axis, in the N-S direction is $300 \mathrm{~m}$ long, while the width of the orebody centres around $200 \mathrm{~m}$. The given parameters indicate that this orebody is very small in size (ČIFLIGANEC, 1993).

\subsection{ANALYTICAL METHODS}

The numerous enclosed analytical data of samples from the Central ore body in the Buchim mine are taken between mine levels $680-560 \mathrm{~m}$ and ocassional samples from the Vršnik ore body between levels $685-650 \mathrm{~m}$. The whole rock analyses $(n=14)$ for major elements were carried out on Li-tetraborate pellets (lithium-tetraborate with a 1:5 mixture of Claisse M4 fluxer) using the X-ray fluorescence method (XRF; Institute of Geochemistry and Petrology; ETH Zürich). Trace element and REE determinations were conducted, also at the ETH Zürich, with laser ablation-inductively coupled plasma-mass spectrometry (LA-ICP-MS) on the same Li-tetraborate pellets and on the zircon grains. The machine is equipped with an Excimer laser (ArF $193 \mathrm{~nm}$ ) and a PE SCIEX Elan 6100 DRC ICP-MS. The spot size of the laser was $40 \mu \mathrm{m}$, and for calibration the NIST 610 standard was used (GÜNTHER et al., 2001; HALTER et al., 2004). Isotopic analysis for $\mathrm{Sr}$ and $\mathrm{Nd}$ (isotopic composition of $\mathrm{Sr}$ and $\mathrm{Nd}$ and $\mathrm{Rb}, \mathrm{Sr}, \mathrm{Sm}$ and $\mathrm{Nd}$ concentrations) was measured at ETH Zürich using a TritonPlus Mass spectrometer (thermal ionisation mass spectrometerTIMS) and at the Royal Holloway University of London (RHUL) using a VG354 TIMS with five movable Faraday cups and a Daly detector and ancilliary clean preparation laboratories.

Quantitative elemental analyses of the most interesting ore mineralization samples were performed under a JEOL JXA8200 Electron Probe Micro-Analyser WD/ED Combined Microanalyser (equipped with a SE- and BSE-detector, fiveWDS crystal spectrometer and an EDS analyser) in the analytical facilities at the Institute of Geochemistry and Petrology, ETH Zürich, Switzerland. The selected electron beam conditions were a beam current of $20 \mathrm{nA}$ at an acceleration voltage of $15 \mathrm{kV}$. An Optima dual inlet mass spectrometer was used with the following preparation systems attached to it: LaserPrep, designed and built at RHUL for laser heating of minerals in an atmosphere of $\mathrm{BrF}_{5}$ to release oxygen for the measurement of ${ }^{18} \mathrm{O} /{ }^{16} \mathrm{O}$ and ${ }^{17} \mathrm{O} /{ }^{16} \mathrm{O}$ ratios and Fisons (NCS EA1500 series 2), an elemental analyser for flash combustion of rocks, soils and vegetation in an oxygen atmosphere to release $\mathrm{CO}_{2}, \mathrm{~N}_{2}$ or $\mathrm{SO}_{2}$ for isotopic analysis. With regard to $\delta^{13} \mathrm{C}$ and $\delta^{18} \mathrm{O}$, syngenetic calcites were analyzed, while $\delta^{34} \mathrm{~S}$ analysis was performed on hypogene sulfides (chalcopyrite, pyrite \pm galena).

Fluid inclusion studies were conducted at the Geological Department of the Royal Holloway University of London in the UK, on samples of doubly polished transparent wafers of quartz and calcite (150 $\mu \mathrm{m}$ thick), where for each sample, at least 20 inclusions were analysed. Microthermometric data were obtained using a Linkam THMSG600 heating-freezing stage (temperature range $-196^{\circ} \mathrm{C}$ to $+600^{\circ} \mathrm{C}$ ) and TMS 90 controller attached to a conventional petrographic microscope (Nikon and Olympus BX51). The stage was calibrated using the Synflinc synthetic fluid inclusions (precision $\pm 0.1^{\circ} \mathrm{C}$ for freezing runs and $\pm 5^{\circ} \mathrm{C}$ for temperatures near to or higher than $360^{\circ} \mathrm{C}$ ). Fluid inclusion homogenization temperatures 
were measured at least twice. The second measurement was carried out at a slow rate $\left(4^{\circ} \mathrm{C}\right.$ step per minute $)$ close to the last $20^{\circ} \mathrm{C}$ approaching the previous measurement of homogenization temperature.

\subsection{ORE MINERALOGY}

More than three decades of study of this deposit have shown that it is characterized by a complex mineral assemblage and mineral paragenesis. Numerous authors have studied the mineral association in the Bučim deposit: IVANOV \& JASMAKOVSKI (1970), ZARIĆ (1974), PAVIČEVIĆ \& RAKIĆ (1983), NEVENIĆ (1984), ČIFLIGANEC (1987), SERAFIMOVSKI (1990, 1993); SERAFIMOVSKI et al. (1990); ČIFLIGANEC et al. (1997), TASEV (2003); SERAFIMOVSKI et al. (2006); VOLKOV et al. (2010); SERAFIMOVSKI et al. (2013); LEHMANN et al. (2013) etc. A wide variety of minerals have been recognized in the Bučim deposit - both ore bearing and gangue minerals (Fig. 4). The mineral composition of orebodies explored so far does not substantially differ, although there are certain peculiarities in the mineral assemblages.

The major ore mineral is chalcopyrite accompanied by pyrite, magnetite, haematite, cubanite, valleriite, native $\mathrm{Au}$ and bornite. The ore mineralization in the Central Part, in the Bunardžik and Vršnik ore bodies, in terms of mode of occurrence, mineral composition, association of elements, etc., is very similar. Differences can be seen only in the Čukar ore body. The Čukar ore body is a typical example of supergene mineralization in the deposit characterized by the increased grade of $\mathrm{Cu}$ but low ore reserves. The major ore minerals are chalcocite and covellite always accompanied by pyrite, tenorite, rarely native $\mathrm{Cu}$, malachite, azurite etc. Titanite, rutile, magnetite, haematite, chalcopyrite, pyrite, bornite, native $\mathrm{Au}$, molybdenite, petzite, calaverite, and argentite were identified as ore minerals. Enargite, tetrahedrite, galena, and sphalerite are less abundant. The ore mineralization was formed in the following sequence: titanite, rutile, and magnetite crystallized first, followed by pyrrhotite, cubanite, valleriite, and the early generation of chalcopyrite. After deposition of these minerals, the hydrothermal ore forming solution became enriched in sulfur, giving rise to pyrite crystallization. The late chalcopyrite and galena formed as the final stage of ore deposition (SERAFIMOVSKI, 1993).

The recent ore microscope study and electron microprobe analyses have revealed that in the Bučim deposit, in addition to the previously identified minerals of native Au and its tellurides (calaverite and krennerite (SERAFIMOVSKI et al., 1992; SERAFIMOVSKI et al., 2006), electrum and petzite also occur (Table 1; Fig. 5).

Gold content, within coarse-grained chalcopyrite, even in single grains of native $\mathrm{Au}$ show a large variation, ranging from $80 \%$ up to $92 \%$ Au (JEOL JXA-8200 Electron Probe; ETH Zürich). The content of Au within a single native Au grain may vary from $80.30 \%$ in the rim, up to $86 \% \mathrm{Au}$ in the central part of the grain. It reflects changes in the physicochemical conditions within the hydrothermal fluids during the mineralization. The most common form of $\mathrm{Au}$ is as native $\mathrm{Au}$, electrum and petzite.

Certain bismuth \pm selenium minerals (bismuthinite, galenobismutite, krupkaite, friedrichite, emplectite, cosalite, laitakarite and native bismuth) were also identified (Table 1; JEOL JXA-8200 Electron Probe; ETH Zürich). Bismuth-selenium minerals (containing $41.7-99.5 \% \mathrm{Bi}$ and $0.3-13.4 \% \mathrm{Se}$ ) appear
Figure 4. Diagram of mineral successions that genetically belong to the Bučim porphyry hydrothermal $\mathrm{Cu}$-deposit. 
Table 1. Quantitative microanalyses of newly determined Bi, Bi-Se and $\mathrm{Au} \pm \mathrm{Te}$ minerals in the Bučim deposit.

\begin{tabular}{|c|c|c|c|c|c|c|c|c|c|c|c|c|c|c|}
\hline & 1 & 2 & 3 & 4 & 5 & 6 & 7 & 8 & 9 & 10 & 11 & 12 & 13 & 14 \\
\hline Bi (\%) & 99.52 & 97.43 & 78.32 & 79.83 & 54.67 & 52.92 & 55.38 & 61.65 & 64.81 & 41.69 & 42.63 & 80.11 & - & - \\
\hline $\mathrm{Pb}(\%)$ & 0.18 & - & 1.62 & - & 26.64 & 20.68 & 21.05 & - & - & 33.38 & 30.03 & 2.21 & - & - \\
\hline $\mathrm{Cu}(\%)$ & - & 0.42 & 0.47 & 1.82 & 0.92 & 6.28 & 6.55 & 15.06 & 13.9 & - & 9.5 & - & 1.26 & 0.52 \\
\hline Au (\%) & - & - & - & - & - & - & - & - & - & - & - & - & 72.53 & 26.84 \\
\hline $\operatorname{Ag}(\%)$ & & - & & - & - & - & - & 0.99 & 1.59 & 4.96 & 0.7 & - & - & - \\
\hline $\mathrm{Fe}(\%)$ & & 1.14 & - & 101 & - & - & - & 1.9 & 1.07 & - & - & - & 0.68 & - \\
\hline As (\%) & & - & - & - & - & 0.32 & - & - & - & - & - & - & 25.42 & 41.09 \\
\hline Se (\%) & & - & - & & - & 1.12 & - & 1.85 & 2.57 & 0.26 & - & 13.41 & - & - \\
\hline Te (\%) & & - & - & - & - & - & - & - & - & - & - & 1.1 & - & 31.23 \\
\hline S (\%) & & - & 19.17 & 17.26 & 18.42 & 17.53 & 17.71 & 18.42 & 15.9 & 16.84 & 17.2 & 34 & - & - \\
\hline ¿sum & 99.7 & 98.99 & 99.58 & 99.92 & 100.75 & 99.75 & 100.69 & 99.87 & 99.84 & 97.13 & 100.06 & 9993 & 99.89 & 99.68 \\
\hline
\end{tabular}

1. Native bismuth; 2. Native bismuth; 3. Bismuthinite; 4. Bismuthinite; 5. Galenobismutite; 6. Krupkaite; 7. Krupkaite; 8. Emplectite; 9. Emplectite; 10. Cosalite; 11. Friedrichite; 12. Laitakarite; 13. Electrum; 14. Petzite.

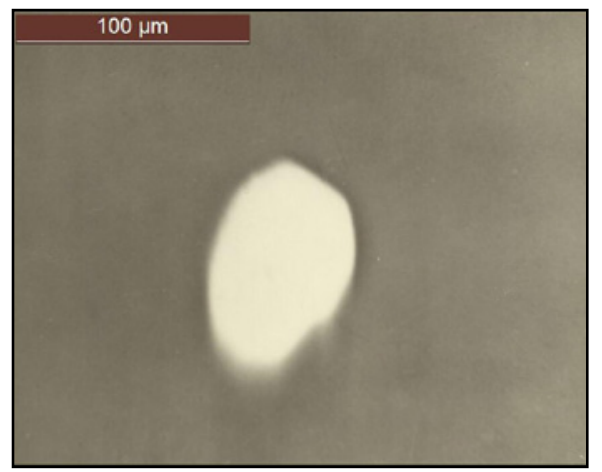

a)

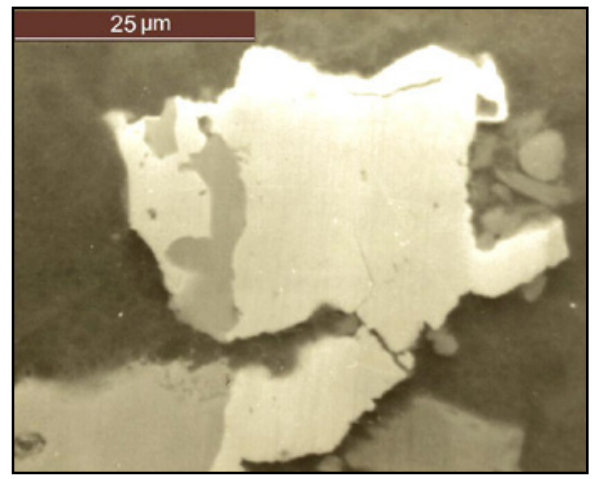

d)

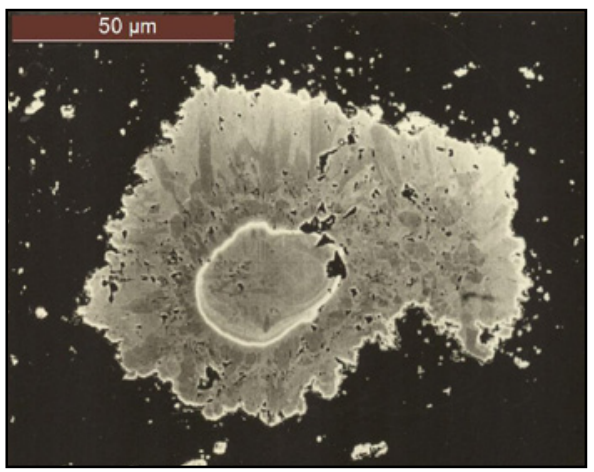

b)

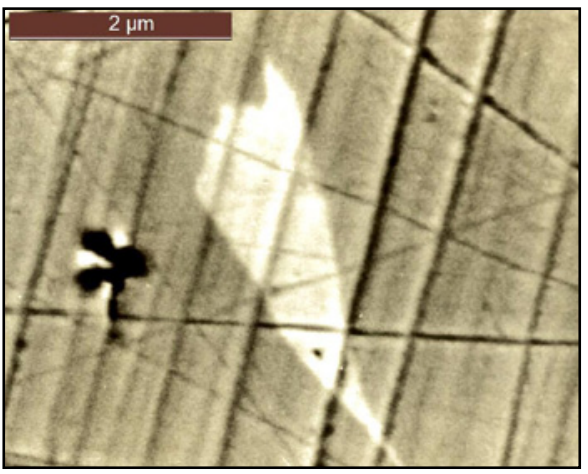

e)

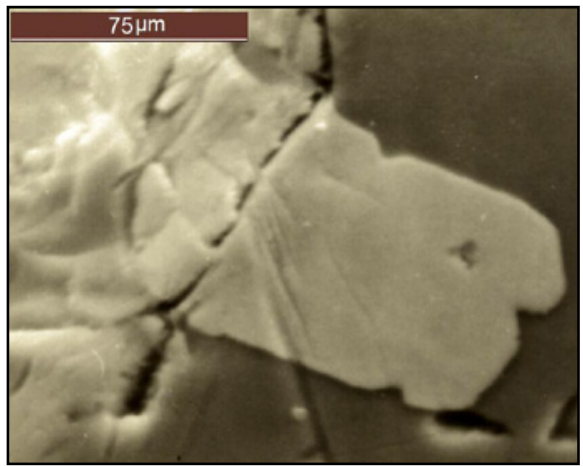

c)

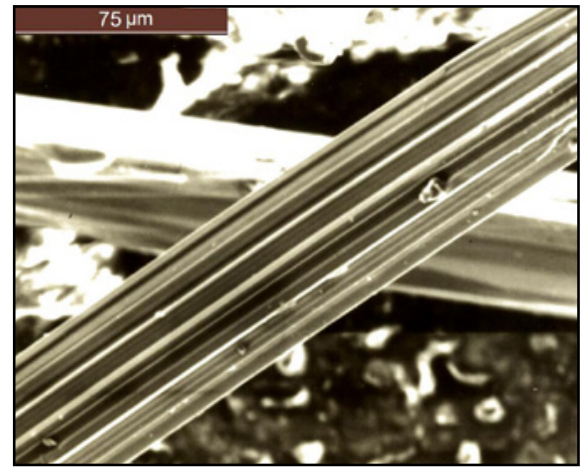

f)

Figure 5. .Electron microprobe photographs of Au and Bi-Se minerals from the Bučim deposit: a) Electrum (white) in chalcopyrite (dark grey), x182; b) Petzite (white-whitegrey) in chalcopyrite (dark), x401; c) Laitakarite-emplectite (whitegrey) in hydrothermally-altered rock (dark), backscattered electron image, x300; d) Bismuthinite (white) along chalcopyrite (grey) in hydrothermally-altered rock (dark), x600; e) Zoned aikinite-bismuthinite aggregate (grey) hosting galena (white) triangular form, x3000; f) Needle-like cosalite crystals, scanning electron microscope. $\mathrm{x} 301$.

to be characteristic of the Au-bearing mineralization of the Bučim $\mathrm{Cu}$ porphyry deposit.

Selenium is not common in the early paragenesis, whereas it is present in krupkaite up to $1.1 \%$ Se, emplectite 1.9-2.5\% $\mathrm{Se}$, while its highest concentration was determined in laitakarite at $13.5 \% \mathrm{Se}$. It is quite possible that during the deposition of laitakarite an influx of Se occurred in the hydrothermal solutions. Within the second ore paragenesis, which also contains particular amounts of bismuth, there are significant amounts of silver - up to $5.0 \% \mathrm{Ag}$, as well as low amounts of selenium, $0.3 \% \mathrm{Se}$.
The most common mineral in the Bučim porphyry $\mathrm{Cu}$ deposit is pyrite present at $3 \%$, while chalcopyrite is the major bearer of $\mathrm{Cu}$ mineralization with a presence of $1 \%$. The Au$\mathrm{Pd}$ association has been determined within the pyrite and chalcopyrite of the major ore-bearing phase in the Central Part orebody. The studied pyrites belong to four different generations and increased concentrations of $\mathrm{Au}$ and $\mathrm{Pd}$ were determined in the so-called blocky pyrites or massive pyrites. The latest microscope and microprobe study have determined two main mineral assemblages: magnetite-pyrite-chalcopyrite (mt-py-cp) and pyrite-chalcopyrite (py-cp), as the major hosts of $\mathrm{Au}$ and $\mathrm{Pd}$. The high degree of geochemical correlation between $\mathrm{Au}, \mathrm{Pd}$ and $\mathrm{As}$ in pyrite and chalcopyrite 


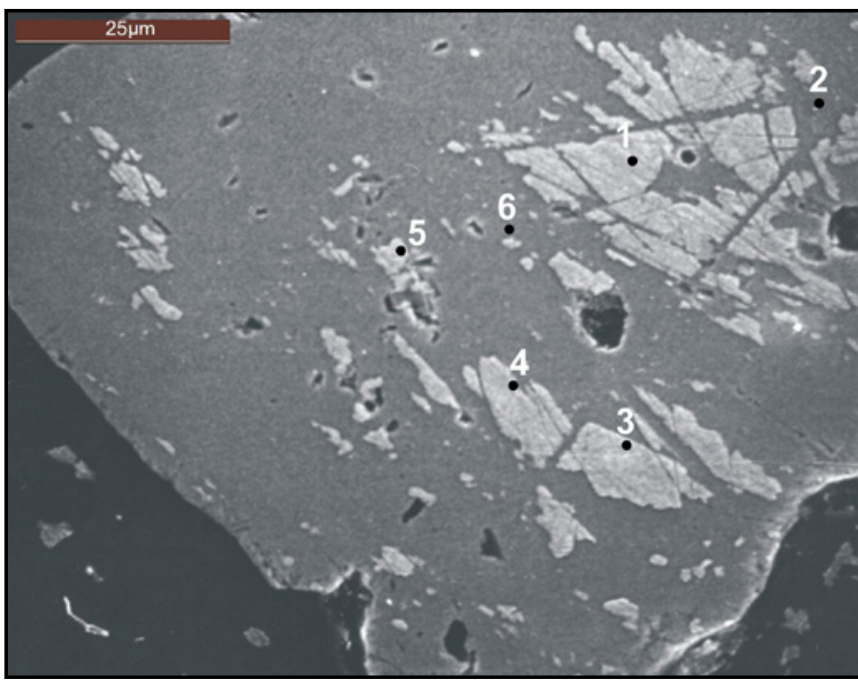

a)

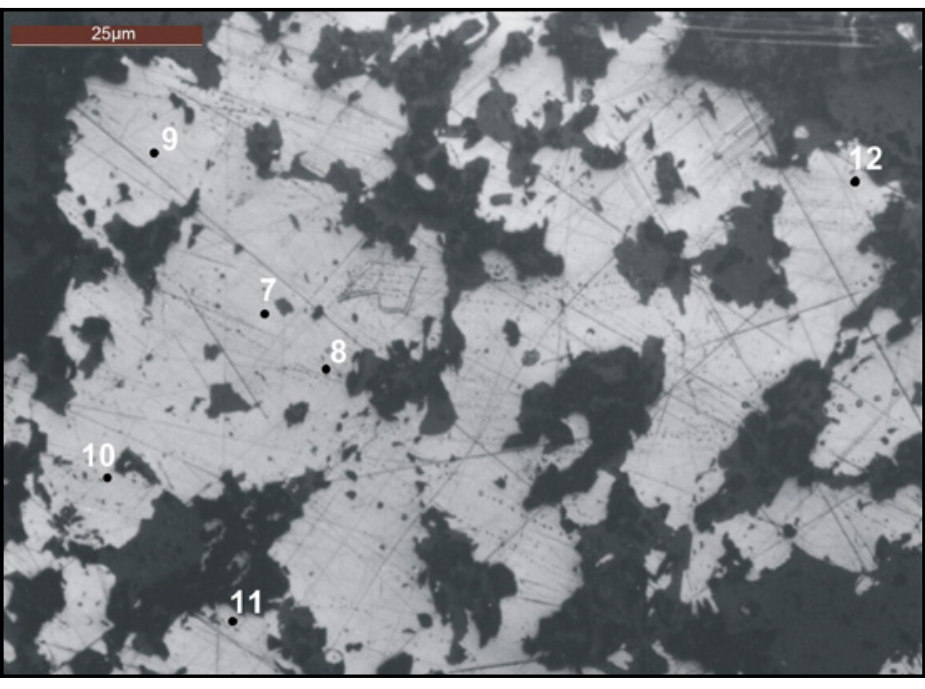

b)

Figure 6. a) Electron microprobe photograph of pyrite (dark) and Au-Pd phases (light grey) and b) Electron microprobe photograph of chalcopyrite, with point analysis.

points to a wide range of physico-chemical conditions and the interplay between magmatic and hydrothermal processes during formation of the deposit.

The Au-Pd phase occurs as a separate mineral phase, which is distinguished by a special colour (pink grey; Fig. 6a). The $\mathrm{Au}$ content in the studied pyrite is within the range of 0.12 $7.54 \% \mathrm{Au}$ while the $\mathrm{Pd}$ content is within the range $0.01-6.33 \%$ $\mathrm{Pd}$, and they are presented as a special mixture of mineral phases characterized by their gray colour (Figure 6a; Table 2).

Increased concentrations of Au-Pd in chalcopyrite are related to the massive, medium-to-high temperature, coarsegraind chalcopyrite, which constitutes the major ore phase within the Bučim deposit (Table 2). However, As in chalcopyrite shows lower values here compared to those in pyrite. The increased content of Pd as well as Pd-mineralization in the
$\mathrm{Cu}-\mathrm{Au}$ ores of the deposit in Bučim, Macedonia has also been determined in Bor-Majdanpek, Serbia (JANKOVIĆ, 1990), Skouries, Greece (TARKIAN et al., 1991; ECONOMOUELIOPOULOS, 2010), and Elatsite, Bulgaria (PETRUNOV et al., 1992), where the Cu-porphyry style of hydrothermal PGE has also been observed. Platinum concentrations were determined only as trace amounts.

\subsection{STABLE ISOTOPE DATA}

\subsubsection{Sulfur Isotope Composition Data}

Sulfur isotope compositions $\left(\delta^{34} \mathrm{~S} \%\right.$ ) normalized to the Canyon Diablo Meteorite $\left(\mathrm{CDM}, \delta^{34} \mathrm{~S}=0.0 \%\right.$ ) show a narrow range of variance from $+6 \%$ to $-4 \%$, pointing to a sulfur origin from the upper mantle, (the fractionation sulfur which has originated from the Upper Mantle or deep homogenized parts

Table 2. Electron microprobe analyses of pyrites and chalcopyrites from the Bučim $\mathrm{Cu}$ porphyry deposit.

\begin{tabular}{|c|c|c|c|c|c|c|c|c|c|c|c|c|}
\hline & 1 & 2 & 3 & 4 & 5 & 6 & 7 & 8 & 9 & 10 & 11 & 12 \\
\hline Au (\%) & 6.98 & 0.21 & 7.75 & 6.51 & 0.12 & 7.54 & 6.34 & 0 & 6.46 & 0.29 & 9.1 & 7.29 \\
\hline $\mathrm{Fe}(\%)$ & 39.29 & 43.64 & 39.18 & 39.98 & 45.46 & 43.56 & 25.92 & 29.08 & 25.13 & 29.11 & 25.97 & 25.73 \\
\hline S (\%) & 44.65 & 53.93 & 46.17 & 44.4 & 53.53 & 47.34 & 28.74 & 34.32 & 29.74 & 33.6 & 26.96 & 28.64 \\
\hline $\mathrm{Cu}(\%)$ & $<$ d. 1 & $<$ d. 1. & 0.03 & 0.02 & 0.06 & 0.01 & 29.46 & 33.68 & 28.68 & 33.51 & 26.64 & 28.91 \\
\hline As (\%) & 0.16 & $<$ d. 1. & 0.03 & 0.68 & 0.14 & 0.02 & $<\mathrm{d} .1$. & 0.02 & 0.05 & $<$ d. 1. & 0.05 & 0.01 \\
\hline $\operatorname{Ag}(\%)$ & $<$ d. 1. & $<$ d. 1. & $<$ d. 1. & 0 & 0 & 0.73 & $<$ d. 1. & $<$ d. 1. & $<\mathrm{d} .1$ & $<$ d. 1. & $<$ d. 1. & $<$ d.1. \\
\hline Pd (\%) & 6.64 & 0.01 & 6.02 & 5.65 & 1.23 & 0.04 & 7.38 & 0.02 & 8.11 & 0.3 & 7.97 & 6.81 \\
\hline Ge (\%) & 0.31 & 0.45 & 0.25 & $<$ d. 1. & $<$ d. 1. & 0.21 & 0.22 & $<$ d. 1. & $<$ d. 1 & 0.38 & 0.42 & 0.35 \\
\hline $\operatorname{Zn}(\%)$ & 0.42 & 0 & 0.26 & $<$ d. 1. & $<$ d. 1. & $<$ d. 1. & 0.35 & $<$ d. 1. & $<\mathrm{d} .1$ & 0.44 & 0.36 & 0.41 \\
\hline V (\%) & 0.53 & 0.25 & 0.21 & 0.21 & $<$ d. 1. & 0.22 & 0.38 & 0.37 & $<\mathrm{d} .1$ & 0.42 & 0.44 & 0.45 \\
\hline Ni (\%) & 0.24 & 0.67 & 0.15 & $<$ d. 1. & $<\mathrm{d} .1$ & 0.21 & 0.33 & $<$ d. 1. & $<\mathrm{d} .1$. & 0.35 & 0.41 & 0.48 \\
\hline $\operatorname{Se}(\%)$ & 0.09 & 0 & $<$ d. 1. & 0.52 & $<$ d. 1. & $<$ d. 1. & $<$ d. 1. & 0.33 & 0.22 & $<$ d. 1. & $<$ d. 1. & $<$ d. 1. \\
\hline Bi (\%) & $<$ d.1. & $<$ d. 1. & $<$ d. 1. & 0.65 & $<$ d. 1. & $<$ d. 1. & $<$ d. 1 & 0.42 & 0.31 & $<$ d. 1. & $<$ d. 1. & $<$ d. 1. \\
\hline Te (\%) & $<$ d. 1 & $<\mathrm{d} .1$ & $<\mathrm{d} .1$ & 0.39 & $<\mathrm{d} .1$ & $<\mathrm{d} .1$ & $<\mathrm{d} .1$ & 0.35 & 0.25 & $<\mathrm{d} .1$ & 0.22 & $<$ d. 1. \\
\hline$\Sigma$ sum & 99.07 & 99.16 & 100.04 & 99.01 & 100.55 & 99.88 & 99.12 & 98.59 & 98.94 & 98.4 & 98.53 & 99.08 \\
\hline
\end{tabular}

Note: 1-6. Electron microprobe analysis data of pyrite; 7-12. Electron microprobe analysis data of chalcopyrite; <d. 1. below detection limit. 
of the Earth's crust varies within narrow range of $\pm 10 \%$ compared with the CDM standard, (JENSEN,1959; SAKAI, 1968; GRINENKO \& GRINENKO, 1974; JANKOVIĆ, 1981; SHELTON \& RYE, 1982; ANDREW et al., 1989; and others).

A preliminary study performed on 10 pyrite samples was done by MUDRINIĆ \& PETKOVIĆ (1974). Preceeding analyses confirmed the general trend of sulfur isotope values (TASEV, 2003; SERAFIMOVSKI \& TASEV, 2005). Sulfur isotope composition of the pyrites show little variation, with a slight increase of the heavy sulfur isotope $\mathrm{v}$ the meteoritic one (Table 3).

Variations of the $\delta^{34} \mathrm{~S}$ values for the whole Bučim ore deposit were in the range of $+0.2 \%$ to $+2.5 \%$, with an average value of $+1.0 \%$ (Fig. 7). There is some variation in the $\delta^{34} \mathrm{~S}$ values for particular ore bodies.

The variation in the $\delta^{34} \mathrm{~S}$ values for the different ore bodies was probably caused by the small differences in fracionation

Table 3. Isotopic composition of sulfur in minerals from the Bučim ore field.

\begin{tabular}{|l|l|c|c|}
\hline No. & Ore body & Horizon & $\boldsymbol{\delta}^{\mathbf{3 4}} \mathbf{S \%}$ \\
\hline $\mathbf{1}$ & Čukar & 630 & +2.5 \\
\hline $\mathbf{2}$ & Čukar & 630 & +0.2 \\
\hline $\mathbf{3}$ & Čukar & 630 & +1.0 \\
\hline $\mathbf{4}$ & Central ore body & 605 & +1.5 \\
\hline $\mathbf{5}$ & Central ore body & 605 & +0.4 \\
\hline $\mathbf{6}$ & Central ore body & 605 & +0.7 \\
\hline $\mathbf{7}$ & Vršnik & 650 & +0.0 \\
\hline $\mathbf{8}$ & Vršnik & 650 & +0.4 \\
\hline $\mathbf{9}$ & Vršnik & 650 & +0.8 \\
\hline $\mathbf{1 0}$ & Vršnik & 650 & +2.1 \\
\hline $\mathbf{1 1}$ & Central ore body & 590 & +1.0 \\
\hline $\mathbf{1 2}$ & Central ore body & 590 & +1.2 \\
\hline
\end{tabular}

Note: Data numbered 1-10 from SERAFIMOVSKI et al. (1996), 11-12 from TASEV (2003).

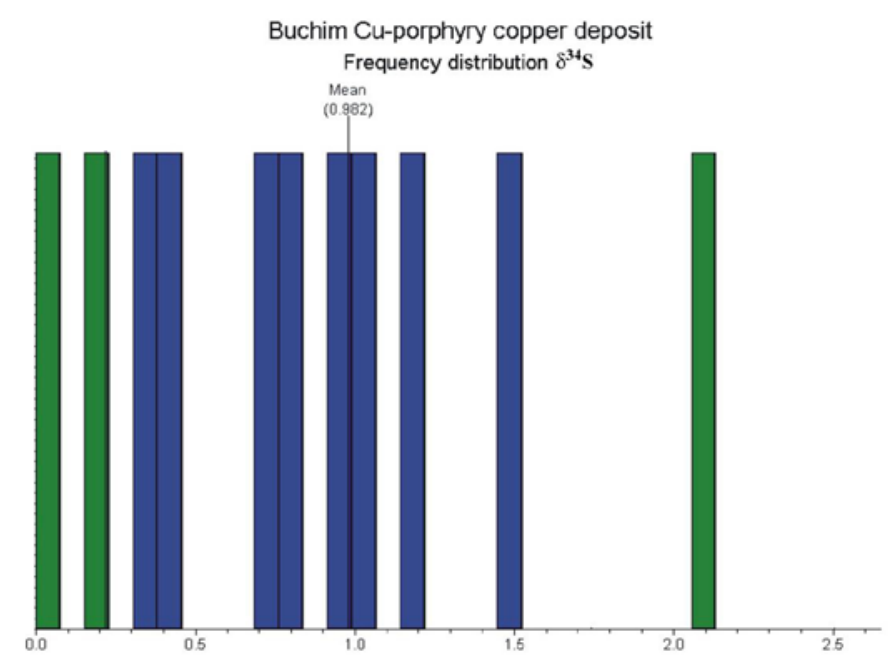

a) grade due to the slight changes of physico-chemical conditions of the ore fluids along the mineralization path.

\subsubsection{Carbon and Oxygen Isotope Composition}

Determination of the origin of the water in hydrothermal solutions relies mainly on data from oxygen fractionation. Isotopic compositions of carbon ${ }^{13} \mathrm{C} /{ }^{12} \mathrm{C}$ and oxygen ${ }^{18} \mathrm{O} /{ }^{16} \mathrm{O}$ were analyzed in calcite samples taken from the Central Part and Cukar ore bodies (Table 4).

The results show narrow ranges for both isotopes, carbon and oxygen, from -10.8 to $-3.8 \%$ and from +14.0 to $+22.7 \%$, respectively. A uniformity in their values, suggests fractionation and a change of the primary isotope compositions of carbon and oxygen from a homogeneous source within a wider porphyry complex.

\subsection{FLUID INCLUSIONS DATA}

Study of fluid inclusions (BLEČIĆ, 1974; STRASHIMIROV et al., 1996, PALINKAS̆ et al., 2008) in quartz from the

Table 4. Isotopic composition of $\mathrm{d} 13 \mathrm{C}$ (PDB) and $\mathrm{d} 18 \mathrm{O}$ (SMOW) in calcite from the ore bodies in the Central Part and Čukar.

\begin{tabular}{|l|l|c|c|c|}
\hline No. & Sample & Mineral & $\boldsymbol{\delta}^{\mathbf{1 3}} \mathbf{C \% o}$ & $\boldsymbol{\delta}^{\mathbf{1 8}} \mathbf{O \% o}$ \\
\hline $\mathbf{1}$ & Central ore body & Calcite & -10.4 & +17.6 \\
\hline $\mathbf{2}$ & Central ore body & Calcite & -7.8 & +22.6 \\
\hline $\mathbf{3}$ & Central ore body & Calcite & -6.9 & +18.9 \\
\hline $\mathbf{4}$ & Central ore body & Calcite & -6.4 & +20.5 \\
\hline $\mathbf{5}$ & Central ore body & Calcite & -5.8 & +21.4 \\
\hline $\mathbf{6}$ & Central ore body & Calcite & -3.8 & +19.7 \\
\hline $\mathbf{7}$ & Central ore body & Calcite & -4 & +22.7 \\
\hline $\mathbf{8}$ & Central ore body & Calcite & -6.4 & +17.1 \\
\hline $\mathbf{9}$ & Central ore body & Calcite & - & +21.4 \\
\hline $\mathbf{1 0}$ & Cukar & Calcite & -10.8 & 14 \\
\hline $\mathbf{1 1}$ & Central ore body & Calcite & -6 & +21.7 \\
\hline
\end{tabular}

Note: Data numbered 1-10 from SERAFIMOVSKI et al. (1996), 11 from TASEV (2003).

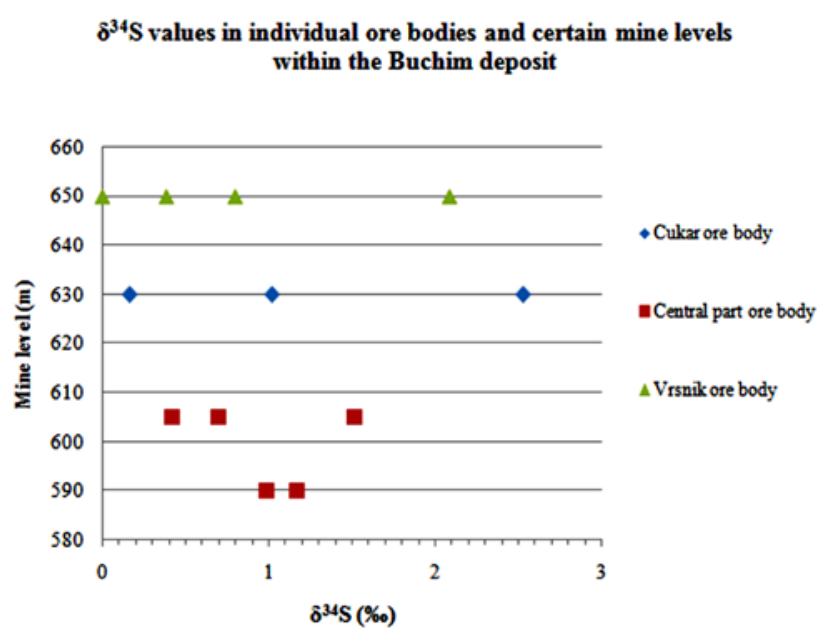

b)

Figure 7. a) Frequency distribution of sulfur isotope values for sulfides from the Bučim Cu-porphyry deposit and b) sulfur isotope values in particular ore bodies at particular mine levels. 
Bučim deposit indicated that ore-bearing $\mathrm{Cu}-\mathrm{Au}$ solutions were predominantly of the $\mathrm{Na}-\mathrm{Cl}$ type, in which concentration of dissolved salts varies between 10 and $25 \%$ wt eq. $\mathrm{NaCl}$, with density from 0.6 to $0.8 \mathrm{~g} / \mathrm{cm}^{3}$ (according to methods given in ROEDDER, 1984; STERNER et al., 1988; VANKO et al., 1988 and BODNAR, 1993). The low content of post-ore calcite in veinlets in the Bučim deposit indicates the more basic nature of the hydrothermal solutions $(\mathrm{pH}$ greater than 7).

The latest study of fluid inclusions was conducted on transparent polished sections made from samples of quartz veinlets and nests, from the primary mineralization. Although quartz is widely distributed in the ore field, it generally forms translucent gray aggregates, and therefore suitable material for the fluid inclusion study is very rare. The majority of fluid inclusions were found in samples from the Central ore body at horizon 540. About 540 different individual measurements were made on the most representative fluid inclusions (Table 5).
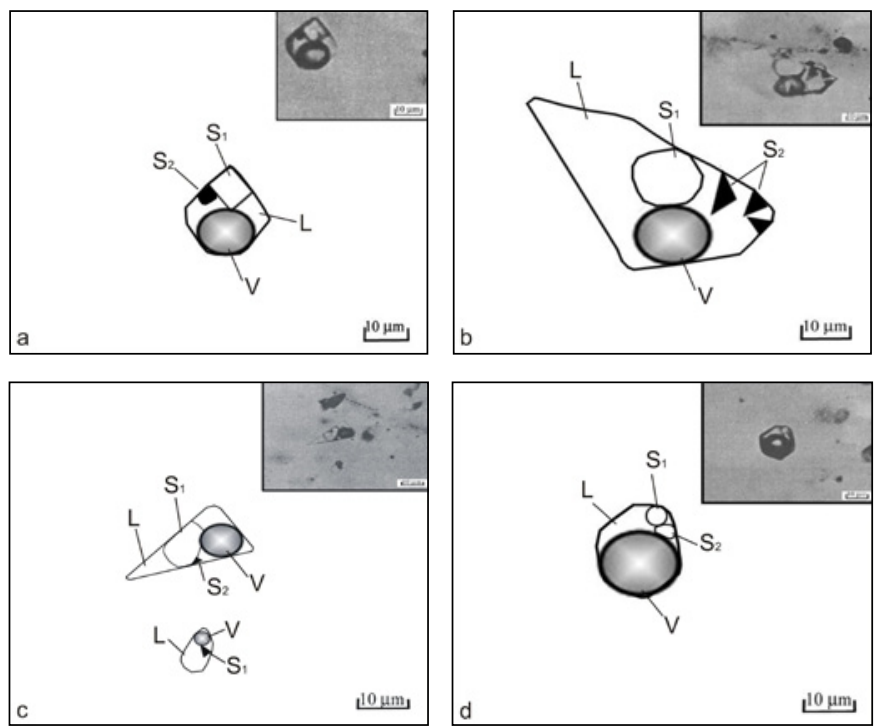

Figure 8. Different types of inclusions in quartz from the Bučim deposit (scale bar $=10 \mu \mathrm{m})$. a) three-phase fluid inclusion (liquid+gas + solid), containing a well-faceted crystal of $\mathrm{NaCl}$, dark gas bubble, liquid and an opaque mineral; b) three-phase fluid inclusion with haematite (hm) and a rounded $\mathrm{NaCl}$ crystal (hl); c) three phase fluid inclusion with a triangular shape; d) three-phase primary fluid inclusion having negative crystal faces in the quartz.
As indicated, the well-faceted quartz crystals are not typical of the Bučim deposit, which complicates the use of known criteria for inclusion division into primary and secondary types. By the definition of ERMAKOV \& DOLGOV (1979), the majority of the studied fluid inclusions were unzoned primary inclusions. Besides the dominant gas-liquid, two-phase inclusions, there are also three-phase fluid inclusions (gas + liquid + solid phase). The latter were usually larger in size (1-35 $\mu \mathrm{m})$ and contain dark gas bubbles and dark, transparent or opaque solids. The number of solids reached up to five (STRASHIMIROV et al., 1996). Transparent solid phases, probably $\mathrm{KCl}$ (STRASHIMIROV et al., 1996), generally were well faceted (Figure 8a). Flat hexagonal flake-like crystals of haematite (probably specularite; Figure $8 \mathrm{~b}$ ), were evidenced by their shape and pinkish-red color. Where present, at the highest recorded temperatures $\left(500-550^{\circ} \mathrm{C}\right)$, specularite also dissolved.

The shape of three-phase inclusions was usually isometric, rarely triangular (Fig. 8c), elongated or having negative faceted crystal forms (Fig. 8d). Some two-phase inclusions contain dark gas bubbles, and the ratio between gas and liquid in them varies from 1.1 to 1.6. Secondary inclusions are elongated and irregular in shape and contain smaller bubbles.

Homogenization temperatures measured in different types of inclusions were classified into several distinct ranges. Highest temperatures $\left(500^{\circ} \mathrm{C}-550^{\circ} \mathrm{C}\right)$ were measured in the three-phase inclusions containing more than one solid phase (Table 5). Several inclusions of this group did not experience homogenization at temperatures more than $580^{\circ} \mathrm{C}$.

Homogenization temperatures of fluid inclusions with one solid phase were in the range $500-530^{\circ} \mathrm{C}$. The majority of transparent solids disappear in the range from 350 to $400^{\circ} \mathrm{C}$, which confirms the presence of halide crystals. High-temperature three-phase inclusions were present in the quartz, associated with haematite, magnetite and rutile in the ore sample. A small group of two-phase inclusions homogenized at temperature ranges from 490 to $460^{\circ} \mathrm{C}$. They contain large dark bubbles (gas: liquid ratio is from 1.1 to 3.1 ) and sometimes homogenized into gas (a sign of boiling!). Mineral paragenesis includes quartz, pyrrhotite, pyrite and chalcopyrite. The largest group of two-phase inclusions homogenized at temperatures of $430-400^{\circ} \mathrm{C}$. They apparently reflect the temperature range of massive chalcopyrite deposition from

Table 5. Temperatures of homogenization in different types of inclusions in quartz.

\begin{tabular}{|l|l|c|c|}
\hline Mineral association & Inclusion type & $\begin{array}{c}\text { No. of measured } \\
\text { inclusions }\end{array}$ & $\begin{array}{c}\text { Homogenization } \\
\text { temperatures range (OC) }\end{array}$ \\
\hline Quartz, K-feldspar & Three phases with 2, 3 or more solid phases & 7 & over 580 \\
\hline Quartz, magnetite, haematite, rutile & Three phases, solid phase halite-haematite & 25 & $500-550$ \\
\hline Quartz, magnetite, haematite, rutile & Three phases & 58 & $530-550$ \\
\hline $\begin{array}{l}\text { Quartz, pyrrhotite, chalcopyrite } \pm \\
\text { cubanite, valleriite }\end{array}$ & Two phases fluid inclusions, large gas bubble & 22 & $430-490$ \\
\hline Quartz, pyrite, chalcopyrite & Two phases & 80 & $400-430$ \\
\hline $\begin{array}{l}\text { Quartz, pyrite, chalcopyrite } \pm \text { bis- } \\
\text { muthinite, enargite }\end{array}$ & Two phases, relatively small bubble & 21 & $320-370$ \\
\hline Quartz, pyrite & Two phases, probably secondary origin & 17 & $180-200$ \\
\hline
\end{tabular}


solutions. The temperature intervals $320-360^{\circ} \mathrm{C}$ and 200 $180^{\circ} \mathrm{C}$ correspond to the influx of the hydrothermal fluids with increased influence of terrestrial waters.

\subsection{GEOCHRONOLOGICAL AND Sr-Nd DATA}

The Tertiary magmatism and its products in the area of interest, are described in extensive literature (KARAMATA, 1974; JANKOVIĆ \& PETKOVIĆ, 1974; JANKOVIĆ, 1977; KARAMATA \& DJORDJEVIĆ, 1980; BOEV et al., 1992; KNEŽEVIĆ et al., 1989; SERAFIMOVSKI, 1990, 1993, 1996; BOEV \& YANEV, 2001; SERAFIMOVSKI et al., 2010; and LEHMANN et al., 2013).

Timing of the intrusions in the Bučim deposit have been studied on several occasions. The analysis of K/Ar whole rock ages of andesitic to trachyandesitic intrusions ranged between 27.5 and $24.7 \mathrm{Ma}$ (SERAFIMOVSKI, 1990; ČIFLIGANEC, 1993; SERAFIMOVSKI et al., 2010). Later studies of the magmatism age at the Bučim area narrowed the age span to between $24.51 \pm 0.89$ and $24.04 \pm 0.77 \mathrm{Ma}$, as indicated by chemical-annealing (CA)-LA ICP-MS zircon dating (LEHMANN et al., 2013).

Recent data (Table 6) reported in the works of BOEV et al. (1992), SERAFIMOVSKI $(1990,1993)$, SERAFIMOVSKI et al. (1996) and TASEV (2003) based on isotopes of ${ }^{87} \mathrm{Sr} /{ }^{86} \mathrm{Sr}$ (0.705040-0.706980) as well as contents of rare earth elements (REE; Table 8), indicated that ensuing magmas in the vicinity of Bučim and its surroundings probably developed by mixing of melts from the contact between the continental crust and the upper mantle. The content of micro- and rare earth elements point to a great similarity with the rock types formed in active continental margins (SERAFIMOVSKI, 1990; BOEV et al., 1992; TASEV, 2003; SERAFIMOVSKI et al., 2010).

Also, the recent $\mathrm{Sr}$ and $\mathrm{Nd}$ isotope ratios $\left({ }^{87} \mathrm{Sr} r{ }^{86} \mathrm{Sr} 0.70666\right.$ 0.70741 and ${ }^{143} \mathrm{Nd} /{ }^{144} \mathrm{Nd} 0.512487-0.512489$; Table 7) show that the magmatic products were slightly contaminated by continental crust material, due to partial melting of the deep parts of continental crust underthrust by collison of continetal blocks.

In the Late Eocene-Oligocene belt, magmatism between 29 and $35 \mathrm{Ma}$ is dominated by crustal melting with increased mantle contribution between 20 and $27 \mathrm{Ma}$.

\subsection{RARE EARTH ELEMENTS}

Rare earth elements (REE) analyses have been performed on various rocks from the Bučim deposit (Table 8).
Calculated $\mathrm{Eu}$ anomaly values ranged from 0.7409 to 0.9036 (TASEV, 2003; SERAFIMOVSKI et al., 2010), which implies a negative Eu anomaly (ROLLINSON, 1992), and is very similar to the recent $\mathrm{Eu}$ anomaly data which range between 0.68893-0.91251 determined by LEHMANN et al. (2013). Distribution of the trace elements, enrichment of large ion lithophile elements (LILE) and depletion in high field strength elements (HFSE), indicates subduction-related magmatism. Most of the magmas follow a calc-alkaline fractionation trend with shoshonitic affinities. Additionally, $\mathrm{Sr} / \mathrm{Y}$ (7 to 70 ) and $\mathrm{La} / \mathrm{Yb}$ ratios (9 to 46) show some similarities with adakite type magmas (SERAFIMOVSKI et al., 2010).

\section{DISCUSSION}

Interpretation of the evolution of the Bučim porphyry $\mathrm{Cu}$ deposit is based on the detailed studies of SMIRNOV (1976), OVTCHINIKOV (1976); JANKOVIĆ (1981, 1990), KRIVTSOV (1983), MITCHEL \& GARSON (1984), OHMOTO (1986), ČIFLIGANEC (1987, 1993), SOTNIKOV et al. (1988), SERAFIMOVSKI $(1990,1993)$ and others.

A general model of the development of the Bučim poprhyry $\mathrm{Cu}$ deposit which considers ore components from their ultimate source to the place of deposition relies on the following issues: origin of the ore metals; origin of ore-bearing solutions; physical-chemical conditions for ore-bearing fluids; deposition of ore components; occurrences which accompany the formation of ore deposits as well as the origin of the magma. This paper gives a brief account of all these phenomena exemplified on the Bučim porphyry $\mathrm{Cu}$ deposit.

The major ore mineral is chalcopyrite accompanied by pyrite, magnetite, haematite, cubanite, valleriite, native $\mathrm{Au}$, and bornite. The ore mineralization in the Central Part, Bunardžik and Vršnik ore bodies is very similar in terms of the mode of occurrence, mineral composition, association of elements etc. Differences can only be seen in the Čukar ore body. The Čukar ore body is a typical example of supergene mineralization characterized by increased grade of $\mathrm{Cu}$ but low ore reserves. The major ore minerals are chalcocite and covellite, always accompanied by pyrite, tenorite, rarely native $\mathrm{Cu}$, malachite, azurite etc. Titanite, rutile, magnetite, haematite, chalcopyrite, pyrite, bornite, native $\mathrm{Au}$, molybdenite, petzite, calaverite, and argentite were identified as ore minerals. Enargite, tetrahedrite, galena, and sphalerite are less abundant.

Genesis of the bismuth \pm selenium minerals (bismuthinite, galenobismutite, krupkaite, friedrichite, emplectite, cosalite,

Table $6 .{ }^{87} \mathrm{Sr} /{ }^{86} \mathrm{Sr}$ data for magmatic rocks from the Bučim deposit.

\begin{tabular}{|l|l|l|l|}
\hline No. & Sample & Rock type & ${ }^{87} \mathbf{S r}{ }^{86} \mathbf{S r}$ \\
\hline $\mathbf{1}$ & BMS1 & Latite & 0.707 \\
\hline $\mathbf{2}$ & BMS2 & Andesite & 0.707 \\
\hline $\mathbf{3}$ & BMS3 & Andesite & 0.707 \\
\hline $\mathbf{4}$ & BMK27 & $\begin{array}{l}\text { Trachy- } \\
\text { andesite }\end{array}$ & 0.705 \\
\hline $\mathbf{5}$ & BMK31 & $\begin{array}{l}\text { Trachy- } \\
\text { dacite }\end{array}$ & 0.707 \\
\hline
\end{tabular}

Table 7. ${ }^{87} \mathrm{Sr} /{ }^{86} \mathrm{Sr}$ and ${ }^{143} \mathrm{Nd} /{ }^{144} \mathrm{Nd}$ data for magmatic rocks from the Bučim deposit.

\begin{tabular}{|l|l|l|l|l|l|}
\hline Sample & ${ }^{87} \mathbf{S r}{ }^{\mathbf{8}} \mathbf{S r}$ & $\begin{array}{l}{ }^{87} \mathbf{S r} /{ }^{86} \mathbf{S r} \\
(\text { corrected } \\
\text { at 24 Ma) }\end{array}$ & ${ }^{143} \mathbf{N d} /{ }^{144} \mathbf{N d}$ & $\begin{array}{l}{ }^{143} \mathbf{N d} /{ }^{144} \mathbf{N d} \\
\text { (corrected } \\
\text { at 24 Ma) }\end{array}$ & $\begin{array}{l}\mathbf{\varepsilon}-\mathbf{N d} \\
\text { (at 24 Ma) }\end{array}$ \\
\hline $\mathbf{2 6 8 - 1 - A}$ & 0.707 & 0.707 & 0.513 & 0.512 & -2.31 \\
\hline $\mathbf{2 4 8 - 2}$ & 0.707 & 0.707 & 0.513 & 0.512 & -2.31 \\
\hline $\mathbf{0 5 9 - 1}$ & 0.707 & 0.707 & 0.513 & 0.512 & -2.3 \\
\hline $\mathbf{2 3 8 - 3}$ & 0.708 & 0.707 & 0.513 & 0.512 & -2.34 \\
\hline
\end{tabular}


laitakarite and native bismuth) within the deposit has been related to two stages of the mineralizing process. The first one: bismuthinite, galenobismutite, friedrichite, krupkaite, emplectite and native bismuth is related to the formation of quartzpyrite-chalcopyrite paragenesis. The second one: bismuthinite, galenobismutite, friedrichite, krupkaite, emplectite, native bismuth and cosalite is associated with a later paragenesis of quartz, pyrite, marcasite and chalcopyrite, (but earlier than the quartz-galena-chalcopyrite stage). Increased $\mathrm{Cu}$ and Fe concentrations in the Bi-Se minerals could be related to the corrosive alteration of chalcopyrite (SERAFIMOVSKI et al., 1990), although numerous examples of isomorphism were determined too. Also, the $\mathrm{Bi} \pm \mathrm{Se}$ mineralization could be prudently considered as the typomorph of endogene Au mineralization in the Bučim deposit.

The Au-Pd association has been determined within the pyrite and chalcopyrite of the major ore-bearing phase in the Central Part orebody in the Bučim deposit. Increased Au and palladium concentrations within pyrite are directly associated with decreased concentrations of iron and sulfur as the major constituents of pyrite, which in practice means that there is substitution of major pyrite constituents by $\mathrm{Au}$ and $\mathrm{Pd}$.

The Au-Pd concentrations in chalcopyrite are probably related to the mixed mineral phases that were unable to discriminate fully. Beside the presence of Au-Pd in chalcopyrite, confirmed by SERAFIMOVSKI (1993) and SERAFIMOVSKI et al. (2006), in the present study there is confirmation of numerous mineral phases such as Bi-Se minerals, laitakarite, friedrichite, cosalite, and others.

Gold and Pd form such a mixture in the main mineral phase in pyrite and chalcopyrite equally (temperatures around $250^{\circ} \mathrm{C}$ ). Their absence in the following phases of the ore-bearing process could indicate stabilization of the crystal lattice of pyrite and chalcopyrite in the later stage of the deposit evolution (TARKIAN et al., 1991; PETRUNOV et al., 2001; ECONOMOU-ELIOPOULOS, 2010).
The very narrow $\delta^{34} \mathrm{~S}$ interval $(+0.2$ up to $+2.5 \%$, averaging $+1.0 \%$ ), is a direct consequence of the homogeneous and quite similar physico-chemical conditions during the formation of sulfide parageneses in all of the three ore bodies in the deposit. The range of $\delta^{34} \mathrm{~S}$ values in pyrites from all three ore bodies points to an endogeneous origin of the sulfur. A dominantly magmatic source of sulfur in porphyry deposits is consistent with the source rocks for porphyry magmas discussed below $\left({ }^{87} \mathrm{Sr} /{ }^{86} \mathrm{Sr} \mathrm{i}{ }^{144} \mathrm{Nd} /{ }^{143} \mathrm{Nd}\right.$ ratios, MISRA, 2000, LEHMANN et al., 2013). Owing to higher sulfur solubilities, predominantly as $\mathrm{SH}^{-}$, in more oxidized I-type hydrous magmas (BURNHAM \& OHMOTO, 1980), the degree of partial melting is sufficient to extract all of the sulfur from the source rocks, and such magmas may commonly contain in excess of $0.2 \mathrm{wt} \% \mathrm{~S}$ (comparEd with perhaps an order of magnitude less sulfur in low $f \mathrm{O}_{2}, \mathrm{~S}$ type magmas).

In accordance with existing classifications and the results obtained for $\delta^{34} \mathrm{~S}$, this deposit could be classified in the first group with an interval from 0.0 up to $0.5 \%$ o $\delta^{34}$ S. OHMOTO \& RYE (1979) pointed out that the deposits which belong to this group of values are closely related to felsic igneous rocks (MISRA, 2000; Fig. 9). The sulfur in the deposit is of igneous origin and was obtained during release from the silicate melt or from sulfides in igneous rocks. Nevertheless, the origin of the $\mathrm{Cu}$ in the Bučim deposit has been related to the primary magmatic intrusion. Since the igneous bodies (dykes and small stocks) were too small for mobilization of the hydrothermal convective systems, the source of $\mathrm{Cu}$ should be related to the existence of deeper and larger igneous bodies.

The fact that $\mathrm{Cu}$ could be mobilized from the serpentinites, which are lying in the basement of the area where ophiolitic complexes were embedded, should also be taken into consideration. This scenario is of special interest if we keep in mind that the Neogene calc-alkaline igneous complexes of the Serbo-Macedonian province are poor with respect to $\mathrm{Cu}$.

Table 8. Contents of rare earth elements in intrusive and volcanic rocks of the Bučim deposit (ppm).

\begin{tabular}{|c|c|c|c|c|c|c|c|c|c|c|c|c|c|c|}
\hline & 1 & 2 & 3 & 4 & 5 & 6 & 7 & 8 & 9 & 10 & 11 & 12 & 13 & 14 \\
\hline Sample & MK27 & MK30 & MK31 & MK32 & $\begin{array}{l}059 / 3 \\
\text { Bun. }\end{array}$ & $\begin{array}{l}059 / 1 \\
\text { Bun. }\end{array}$ & $\begin{array}{c}\text { 268/1/A } \\
\text { Cen. P }\end{array}$ & $\begin{array}{c}238 / 3 \\
\text { Vrš }\end{array}$ & $\begin{array}{c}238 / 4 \\
\text { Vrš }\end{array}$ & $\begin{array}{c}228 / 1 \\
\text { Vršs }\end{array}$ & $\begin{array}{c}248 / 2 \\
\text { Vršs }\end{array}$ & $\begin{array}{c}248 / 1 \\
\text { Vršs }\end{array}$ & $\begin{array}{c}056 / 3 \\
\text { Cent. P }\end{array}$ & $\begin{array}{c}056 / 5 \\
\text { Cent. P }\end{array}$ \\
\hline La & 32.78 & 68.27 & 44.86 & 67.52 & 67.3 & 78.7 & 59.7 & 69.3 & 83.6 & 58.4 & 80.7 & 75.4 & 35.1 & 57.1 \\
\hline $\mathrm{Ce}$ & 59.54 & 119.26 & 86.72 & 118.34 & 124 & 141 & 113 & 149 & 170 & 126 & 155 & 141 & 81.3 & 125 \\
\hline $\mathrm{Pr}$ & 7.12 & 13.64 & 10.47 & 12.99 & 13.6 & 14.9 & 12 & 16.2 & 16.5 & 13.7 & 15.8 & 14.7 & 9.4 & 14.9 \\
\hline Nd & 27.07 & 48.2 & 38.8 & 45.95 & 53 & 54.8 & 45.4 & 59.2 & 60.3 & 50.4 & 59.3 & 54 & 38.7 & 60.5 \\
\hline Sm & 5.14 & 8.32 & 7 & 7.66 & 8.5 & 9.7 & 7.9 & 8.9 & 9.7 & 9.3 & 10.5 & 9.2 & 7.7 & 9.6 \\
\hline Eu & 1.45 & 2 & 1.52 & 1.86 & 1.8 & 2 & 1.8 & 2.1 & 2.3 & 1.9 & 2.2 & 2 & 1.5 & 1.9 \\
\hline Gd & 4.7 & 6.79 & 5.56 & 6.14 & 6.8 & 6.4 & 6 & 6.3 & 6.2 & 5.9 & 7.2 & 6.4 & 5.5 & 7.5 \\
\hline $\mathbf{T b}$ & 0.71 & 0.88 & 0.75 & 0.8 & 0.9 & 0.9 & 0.7 & 0.8 & 0.9 & 0.9 & 1 & 0.9 & 0.8 & 0.9 \\
\hline Dy & 3.87 & 4.51 & 3.78 & 4.3 & 4.4 & 4.5 & 4.2 & 4.5 & 4.2 & 5.1 & 5.5 & 4.9 & 5.1 & 4.6 \\
\hline Ho & 0.78 & 0.83 & 0.69 & 0.8 & 0.8 & 0.8 & 0.8 & 0.7 & 0.8 & 0.9 & 0.9 & 0.8 & 0.8 & 1.1 \\
\hline Er & 2.25 & 2.33 & 1.91 & 2.34 & 2.2 & 2.6 & 2.3 & 2.2 & 2.3 & 2.8 & 2.6 & 2.4 & 3 & 2.9 \\
\hline Tm & 0.34 & 0.33 & 0.28 & 0.33 & 0.3 & 0.3 & 0.3 & 0.3 & 0.3 & 0.4 & 0.4 & 0.4 & 0.3 & 0.4 \\
\hline Yb & 2.26 & 2.3 & 1.89 & 2.31 & 2.6 & 2.3 & 2.2 & 2.3 & 1.8 & 2.5 & 2.9 & 2.7 & 3.7 & 2.7 \\
\hline $\mathbf{Y}$ & 23.05 & 24.57 & 20.43 & 24.84 & 25.7 & 243 & 24.2 & 22.9 & 23.6 & 28.4 & 30.2 & 25.6 & 23.4 & 27.7 \\
\hline Lu & 0.33 & 0.34 & 0.28 & 0.34 & 0.4 & 0.3 & 0.3 & 0.4 & 0.3 & 0.4 & 0.4 & 0.3 & 0.5 & 0.4 \\
\hline
\end{tabular}

Note: MK-27 Trachyandesite; MK-30 Trachyandesite; MK-31 Trachydacite; MK-32 Trachydacite ; 059-3 Bun. Trachyandesite; 059-1 Bun. Trachyandesite; 2681-A Cen.P Trachyandesite; 238-3 Vrš. Trachyandesite; 228-1 Vrš. Trachyandesite; 248-2 Vrš. Trachyandesite; 248-1 Vrš. Trachyte; 056-3 Cent. P Trachyte; 056-5 Cent. P Trachyandesite. Data 1-4 from TASEV (2003); 5-14 from LEHMANN et al. (2013). 
Temperatures of the hydrothermal solutions during the formation of ore minerals ranged from $200-300^{\circ} \mathrm{C}$ to $600^{\circ} \mathrm{C}$, with figures as low as $100^{\circ} \mathrm{C}$ for the latest ore occurrences comprising pyrite microfillings.

Temperature calculations from the values of sulfur isotope composition (mineral pairs: galena-chalcopyrite) were in the range of $110^{\circ} \mathrm{C}-160^{\circ} \mathrm{C}$, which in general does not correspond with the majority of temperatures obtained during the fluidinclusion analysis $\left(200 \div 580^{\circ} \mathrm{C}\right.$, BLEČIĆ, 1974; STRASHIMIROV et al., 1996). The isotopic temperatures usually do not correspond with the formation temperatures of the hydrothermal ore deposits, that was well established from fluid inclusion studies elsewhere (BEHR \& GERLER, 1987; BEHR et al., 1987; WERNER et al., 1990; HOFMANN \& EIKENBERG, 1991; GERMAN et al., 1994; LIPPOLT \& WERNER, 1994; LÜDERS, 1994; RITTER, 1995; WEBER, 1997; WERNER et al., 2000). This indicates that ore precipitation occurred under conditions where sulfur isotope equilibrium was not established. This could be possible if we take into account that hydrothermal solutions had near-neutral $\mathrm{pH}$ and the total sulfur concentration was around 500-1000 ppm (STRASHIMIROV et al., 1996). An additional fact comes from the time required to establish a degree of equilibrium of $95 \%$ at $300-350^{\circ} \mathrm{C}$, which is less than one year. In contrast, at temperatures of $150-200^{\circ} \mathrm{C}$, which correspond to the formation temperatures of the sulfide-sulfate pairs, equilibriation needs 3000-7000 years (SCHWINN et al., 2006). Considering the hydrodynamics of fluid migration within the fault zones, it appears plausible that fluid mixing and mineral deposition processes were too rapid for equilibration of sulfur isotopes at formation temperatures. A relatively fast ascent of fluids from a deep source through open fractures is consistent with the tectonic setting of the hydrothermal mineralizations in the Bučim deposit

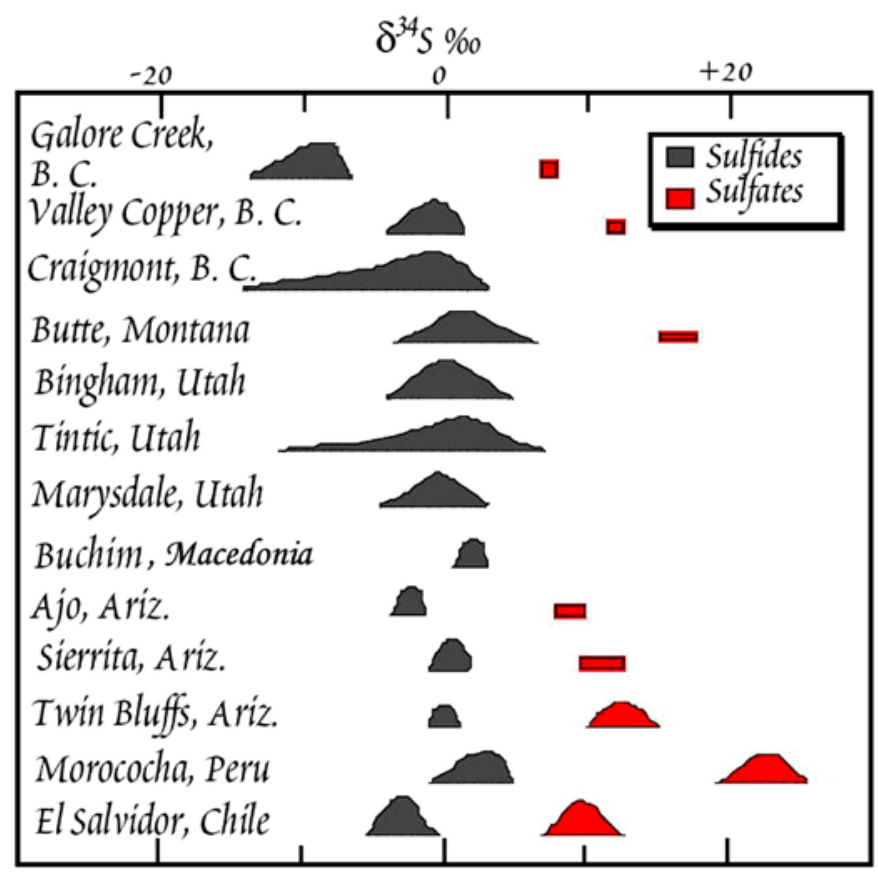

Figure 9. $\delta^{34} \mathrm{~S}$ values in sulfides and sulfates from the porphyry ore deposits. Bučim values of sulfides are included for comparison (modified after OHMOTO \& RYE (1979)).
(SERAFIMOVSKI, 1993). Temperature discrepancies between sulfur isotope calculations and those obtained from fluid-inclusions studies indicate an open system, at least in the final stages, which resulted in disequilibrium sulfur fractionation. In this case we may speak about the existence of kinetic fractionation reactions. So, the S-isotopic equilibrium fractionations between galena and chalcopyrite at the Bučim deposit gave low temperatures that might reflect cooling during the development of the paragenesis (HILL et al., 2015).

Values of $\delta^{13} \mathrm{C}$ range from $-3.84 \%$ o to $-10.83 \%$, which suggests intensive carbon fractionation and enrichment with the lighter carbon isotope. This is common for high temperature calcites (RYE et al., 1974) whereas the carbon isotopic composition changes can be interpreted as a consequence of increase of oxidation potential of hydrothermal solutions and oxidation of $\mathrm{CH}_{4}$ which has a light isotope signature.

The variation of oxygen $\delta^{18} \mathrm{O}$ values in the studied calcites are within the range of $+13.98 \%$ o to $+22.70 \%$. Heavier $\delta^{18} \mathrm{O}$ isotope values in calcite, around $+23 \%$, are close to equilibrim fracionation due to the participation of meteoric water. However, the value of $13.98 \%$ is low and reflects a lowered fracionation factor due to a high formation temperature. Besides, there is significant fractionation of oxygen from the place of formation of the hydrothermal fluid to the place of deposition of mineralization and ore associated carbonates. It should be pointed out that such values are common in hydrothermal carbonates, since they have passed through different tectonomagmatic and geochemical settings. There were real conditions for change of the isotopic composition especially if hydrothermal fluids have different salinity, acidity, concentration, different water/rock ratio etc.

The oxygen variation $\left(\delta^{18} \mathrm{O}\right)$ in samples is in the range that suggests intensive oxygen fractionation and a change of isotopic composition by way of enrichment with the lighter isotope.

The results of fluid inclusions analyses suggest a large temperature range for mineral deposition. Initially, hydrothermal fluids caused a change in the host rocks (replacement of quartz and K-feldspar) at temperatures of $500-600^{\circ} \mathrm{C}$. Fe-Ti oxide mineralization was formed in the same temperature range. Solutions probably were of high salinity $(\sim 30-40$ or more $\% w t$ eq. $\mathrm{NaCl}$ ), as evidenced by the prevalence of three-phase inclusions, with halides, and often with more than one solid phase. As solutions cooled, the role of sulfide in the solution increased, due to disproportionation of sulfur compounds which caused the precipitation of sulphide minerals, pyrrhotite, cubanite, valleriite and small quantities of pyrite and chalcopyrite. Simultaneous fluid inclusion homogenization in the same sample, into gas and liquid, indicates boiling of the hydrothermal solutions in the system. The significant role of sulfur in the solutions is confirmed by the precipitation of pyrite and chalcopyrite in a wide temperature range of fluid homogenization temperatures $\left(430-400\right.$ and $\left.490-400^{\circ} \mathrm{C}\right)$. The absence of three phase inclusions indicates lower salinity at that time. The latest mineral assemblages, containing bismuthinite, enargite, petzite and other minerals, were formed at temperatures of $360-320^{\circ} \mathrm{C}$ and below. The presene of chloride in fluid inclusions suggests the transport of ore components by chlo- 
ride complexes. Circulation of hydrothermal ore-bearing solutions was conducted through the spaces of increased permeability. They are fractured, tectonized, with dense joint-fissure systems, initiated by penetration of primary intrusions (HRKOVIĆ, 1985).

These data indicate the similarity of the formation temperature of the Bučim deposit and the $\mathrm{Cu}$-porphyry deposits Elatsite (in the Panagyuriysky ore district, Bulgaria) and Majdanpek (in the ore district of Bor, Serbia) (STRASHIMIROV \& KOVAČEV, 1992). Common features of these deposits are high temperatures at the beginning of mineralization and the fact that extensive three-phase inclusions in quartz are associated with Fe-Ti mineralizations. The formation temperature of the main $\mathrm{Cu}$ mineralization is well above those in the Medet and Assarel deposits (Panagurishte ore district). The reason for the higher temperatures of ore deposition could be a shorter distance from the source of ore-forming fluids. Hydrothermal systems were relatively closed at the beginning of the process of mineralization, and the influence of meteoric water was also limited. Preliminary isotope data of the sulfide minerals supports the assumption of the endogenous origin of hydrothermal fluids. This data relates mainly to the samples from the central part of the deposit. Additional studies of the upper and marginal portions of the ore field can provide more detailed information on the development and zoning of the hydrothermal system in the Bučim $\mathrm{Cu}$ porphyry deposit.

Based on the age (K/Ar whole rock ages from 27.5 to 24.7 $\mathrm{Ma}$ and narrowed age span obtained by the latest data from 24.51 to $24.04 \mathrm{Ma})$, Strontium isotopes ${ }^{87} \mathrm{Sr} /{ }^{86} \mathrm{Sr}(0.705040$ $0.707410)$ and corrected data of Neodimium isotopes ${ }^{143} \mathrm{Nd} /{ }^{144} \mathrm{Nd}(0.512487-0.512489)$, we suggest the following scenario for the magmatic history of the Bučim-Damjan-Borov Dol ore district. A rollback of an oceanic slab located further to the SW, led to extensional and compressional features in the upper levels of the continental crust. In the middle to upper crust, three consecutive crystallization stages occurred at variable depths as indicated by amphibole zonation. The ascent of the magma through a complex assemblage of continental crust and newly formed crust with mantle affinities in variable degrees explains all the geochemical characteristics. The magma

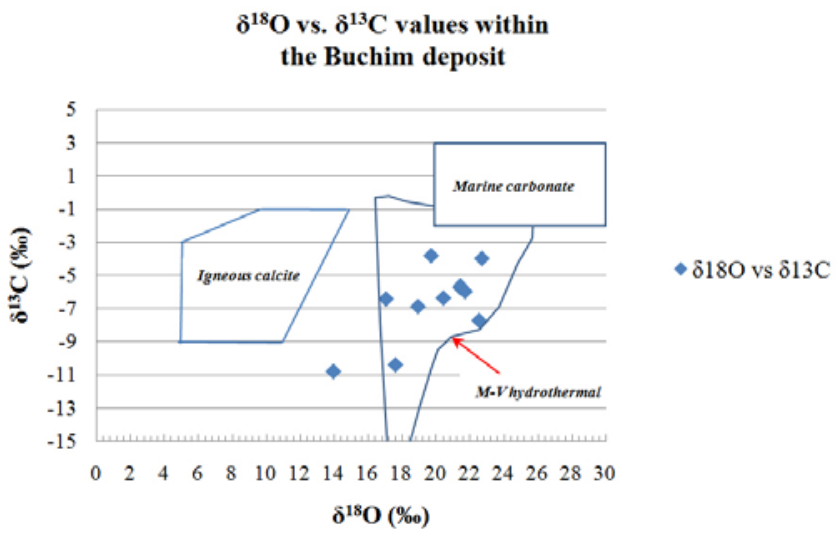

Figure 10. Distribution of $\delta^{13} \mathrm{C}_{\mathrm{PDB}}$ vs. $\delta^{18} \mathrm{O}_{\text {SMOW }}$ showing probable environment of origin (M-V Mantle derived hydrothermal calcites). Isotopic composition from some carbon reservoirs has been shown on the plot (data fields from ROLLINSON, 1992 and RAY et al., 2000). crystallized as dykes or stocks near the Earth's surface after its final emplacement and contemporaneous hydrothermal activity led to different mineralization styles depending on the lithology of the host rocks.

Whole rock ${ }^{87} \mathrm{Sr} /{ }^{86} \mathrm{Sr}(0.706660-0.707410)$ and ${ }^{143} \mathrm{Nd} /{ }^{144} \mathrm{Nd}$ (0.512487-0.512489) isotopic compositions from the recent study are presented in Figure 11. The proposed mixing curve is in agreement with the data from PE-PIPER \& PIPER (2001), as well as with several isotopic analyses available for young magmatic rocks of this region (intrusive rocks from Macedonia, Serbia and Bulgaria (YANEV et al., 2008; PRELEVIĆ et al., 2005; MARCHEV et al., 2004; CVETKOVIĆ et al., 2004 and LEHMANN et al., 2013).

A hyperbolic mixing curve for different ratios of $(\mathrm{Sr} / \mathrm{Nd})$ $\mathrm{EMII} /(\mathrm{Sr} / \mathrm{Nd}) \mathrm{DM}$ shows mixing between a depleted mantle (DM) and an enriched mantle (EMII) source. It illustrates that the measured $\mathrm{Sr}-\mathrm{Nd}$ isotopic ratio is a result of magma mixing or crustal contamination as determined elsewhere in the region (CVETKOVIĆ et al., 2004; DEPAOLO \& WASSERBURG, 1979; MARCHEV et al., 2004; PRELEVIĆ et al., 2005; ROLLINSON, 1992; YANEV et al., 2008).

REE data, the high contents of large ion lithophile elements (LILE), a high $\mathrm{Ba} / \mathrm{Nb}$ ratio (116.72-190.72) and depletion in high field strength elements (HFSE), appropriate to mixing of asthenospheric melts and metasomatized magma (DOWNES et al., 1995), could easily be connected to subduction-related arc magmatism (BOEV et al., 1992; STOLZ et al., 1996). The origin of fluids from metasomatized magma is also indicated by the the REE chondrite normalized pattern (Figure 12), similar to those of KONONOVA et al. (1989) and BOEV \& YANEV (2001), which is close to the theoretical curve of their affinity to an aqueous fluid, reflecting the mobility of elements in this fluid (PEARCE et al., 1981; BOEV \& YANEV, 2001).

Also, we point out that most of the magmas follow a calcalkaline fractionation trend with shoshonitic affinities.

Accordingly, the data for Europium in analyzed samples and its negative anomaly (0.68893-0.91251; Figure 12), suggest that $\mathrm{Eu}$ was removed from the melt as a compatible $\mathrm{Eu}^{2+}$,

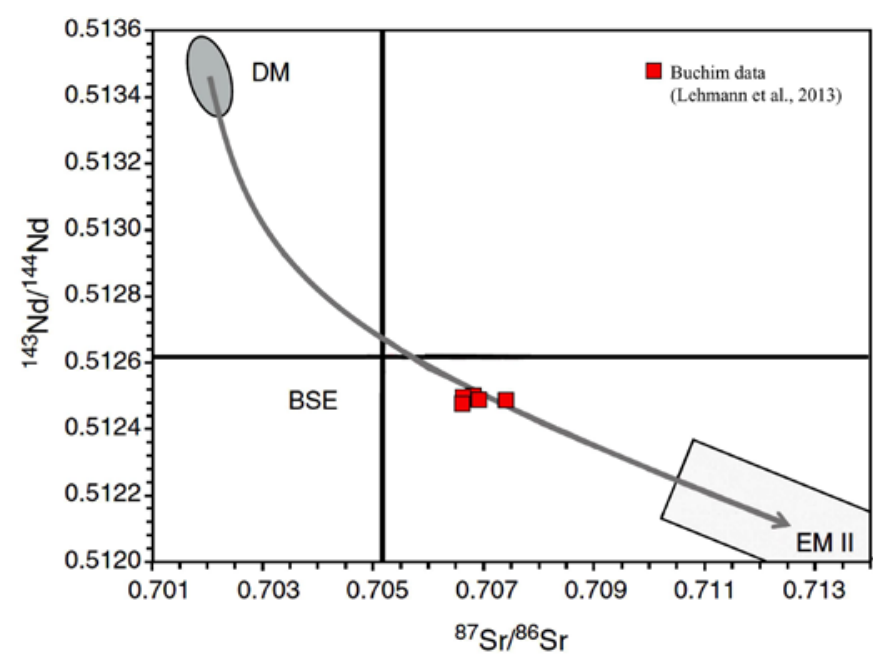

Figure 11. Initial ${ }^{87} \mathrm{Sr} /{ }^{86} \mathrm{Sr}$ vs. initial ${ }^{143} \mathrm{Nd} /{ }^{144} \mathrm{Nd}$ correlation diagram. 
by the processes of crystal fractionation of plagioclases (ROLLINSON, 1992; TASEV et al., 2005).

Most of the samples have a high $\mathrm{Sr} / \mathrm{Y}$ and $\mathrm{La} / \mathrm{Yb}$ ratio, and their multi-element patterns were characterized by depletion in $\mathrm{Nb}$, Ta and $\mathrm{Zr}$, and enrichment of $\mathrm{Pb}$ and $\mathrm{Sr}$ (Table 1). the LILE were enriched relative to the HFSE (Table 2). All these parameters, togehter with several plots $\mathrm{Zr} / \mathrm{Y}$ vs. $\mathrm{Zr}, \mathrm{Ce} / \mathrm{P}_{2} \mathrm{O}_{5}$ vs. $\mathrm{Zr} /$ $\mathrm{TiO}_{2}$ and Ti vs. $\mathrm{Zr}$ (MÜLLER et al., 1992; PEARCE, 1983) point to an apparent continental arc setting (BOEV \& JANEV, 2001).

\section{CONCLUSIONS}

The porphyry $\mathrm{Cu}$ mineralization within the Bučim deposit is spatially and genetically closely related to the small Tertiary volcanic intrusions that have protruded through the Precambrian complex of the Serbo-Macedonian Massif within a time frame of 27.50-24.04 Ma. Spatially, the porphyry Cu mineralization is followed by $\mathrm{Au}$, ocassionally platinum and PGE group and Bi-Se minerals localized as rings around the andesite-latite necks and dykes. The major ore-bearing mineral is chalcopyrite followed by a series of sulfides and sulfosalts.

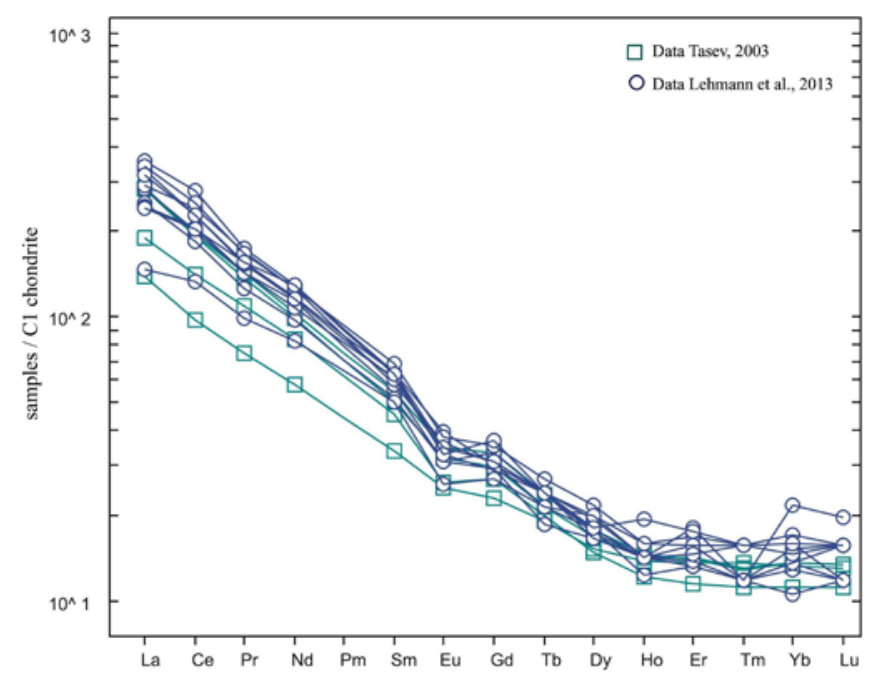

Figure 12. Chondrite normalized REE patterns ( $\mathrm{C} 1$ chondrite values after SUN \& MCDONOUGH, 1989).

Ore mineralization mostly is of endogeneous origin as suggested by the stable istopes of sulfur $\left(\delta^{34} \mathrm{~S}\right.$ from +0.16 up to $+2.53 \%$ averaging $+1.06 \%$ ). The origin of ore metals and their evolution in the hydrothermal system from magma to the site of deposition has been defined by the stable isotopes of carbon $\left(\delta^{13} \mathrm{C}\right.$ in the range from -3.84 to $-10.83 \%$ ) and oxygen $\left(\delta^{18} \mathrm{O}\right.$ within the range from +13.98 to $+22.70 \%$ ), which can be interpreted as being representative of magmatic hydrothermal fluids with a pronounced contribution from meteoric water.

Temperatures of deposition of the major mineralizing paragenesis were defined by a fluid inclusions study, and are within the range of: $500-600^{\circ} \mathrm{C}$ ( $\mathrm{Fe}-\mathrm{Ti}$ oxide mineralization), 400 $490^{\circ} \mathrm{C}$ (precipitation of pyrite and chalcopyrite) and 360 $320^{\circ} \mathrm{C}$ and below (responsible for the late mineral assemblages of bismuthinite, enargite, petzite and some other minerals. Fluid inclusions suggest that the transport of components was most probably by water fluids in the form of chloride complexes and very seldom sulphate and carbonate.

The evolution of the Tertiary magmatism and magma origin was indicated through the ${ }^{87} \mathrm{Sr} /{ }^{86} \mathrm{Sr}$ isotope $(0.705040$ $0.707410)$ and ${ }^{143} \mathrm{Nd} /{ }^{144} \mathrm{Nd}$ isotope ratios $(0.512487-0.512489)$ which confirm magma mixing or crustal contamination. This is in favour of the mixing of asthenospheric melts and metasomatized magma, which could easily be linked to subductionrelated arc magmatism.

\section{REFERENCES}

ANDREW, A., HEINRICH, C., WILKINS, R. \& PATTERSON, D. (1989): Sulfur Isotope Systematics Of Copper Ore Formation At Mount Isa, Australia.- Econ. Geol., 84/6, 1614-1627.

BEHR, H.J. \& GERLER, J. (1987): Inclusions of sedimentary brines in postVariscan mineralizations in the Federal Republic of Germany - a study by neutron activation analysis.- Chem. Geol., 61, 65-77.

BEHR, H.J., HORN, E.E., FRENZEL-BEYME, K. \& REUTEL, C. (1987): Fluid inclusion characteristics of the Variscan and post-Variscan mineralizing fluids in the Federal Republic of Germany.- Chem. Geol., 61, 273-285.

BLEČIĆ, N. (1974): Izveštaj o termobarohemiskim merenjima u rudnim rastvorima fluidnih inkluzija u rudnoj paragenezi Bučimskog ležišta [Report of thermobarochemical measurements in ore solutions fluid inclusions in Bučim 's deposit ore paragenesis - in Serbian].- Profess. Fund of Bučim Mine Geological Survey, PRMB "Bučim" - Radovis, 35 p.

BLEVIN, P. (2002): The Petrographic and Compositional Character of Variably K-Enriched Magmatic Suites Associated with Ordovician Porphyry $\mathrm{Cu}-\mathrm{Au}$ Mineralisation in the Lachlan Fold Belt, Australia.- Min. Dep., 37, 87-99.

BODNAR, R.J. (1993): Revised equation and table for determining the freezing point depression of $\mathrm{H}_{2} \mathrm{O}-\mathrm{NaCl}$ solutions.- Geoch. Cosmoch. Acta, 57, 683-684.

BOEV, B., ČIFLIGANEC, V., STOJANOV, R. \& LEPITKOVA, S. (1992): Oligocensko-Neogen magmatizam vo ramkite na Bučimskiot blok [Oligocene-Neogene magmatism within the Bučim blok area - in Macedonian].- Geol. Maced., 6, 23-32.

BOEV, B. \& YANEV, Y. (2001): Tertiary magmatism within the Republic of Macedonia: a Review.-Acta Vulcan., 13/1-2, 57-71.

BONČEV, G. (1920): Petrographic and mineralogical studies in Macedonia.Collection of Bulgarian Academy of Sciences, Department of Natural sciences and Mathematics, Sofia, 13, 1-295.

BURNHAM, C.W. \& OHMOTO, H. (1980): Late-stage processes of felsic magmatism.- Mining Geol. Spec. Iss., 8, 1-12.

ČIFLIGANEC, V. (1987): Metalogenetske karakteristike ležišta bakra Bučim u Srpsko-Makedonskoj metalogenetskoj provinciji [Metallogenetic features of the Bučim copper deposit in the Serbo-Macedonian metallogenetic province - in Serbian].- Ph.D. Thesis, Faculty of Mining and Geology, Belgrade, Serbia, $190 \mathrm{p}$.

ČIFLIGANEC, V. (1993): Rudišta i pojavi na bakar vo Republika Makedonija: tipovi i reonizacija [Copper Mineralization in the Republic of Macedonia: Types and Distribution Patterns - in Macedonian with extended summary in English].- University "Sts. Cyril and Methodius" Skopje, Faculty of Mining and Geology - Štip, Spec. Issue, 1, 303 p.

ČIFLIGANEC, V. ET AL. (1993): Studija za procenka na zlatonosniot potencijal na Bučimskoto rudno pole vo pogled na istražuvanje na novi rezervi na bakar i zlato [Study for gold potential estimate of the Bučim ore field in regards to exploration of new copper and gold reserves - in Macedonian].- Professional Geological Survey Fund, Radoviš, Macedonia, 95 p.

ČIFLIGANEC, V., SERAFIMOVSKI, T. \& STEFANOVA, V. (1997): Content and Distribution of Gold-Bearing Minerals from the Bučim Porphyry Copper Deposit.- Symposium-Annual Meeting-Dojran, Proceeding, Abstract, 1, 277-278.

CULEV, G. (1970): Detalni geohemiski istražuvanja na bakar vo 1969 [Detailed geochemical exploration of copper in 1969 - in Macedonian].Specialist Fund of the Geological Survey of the Republic of Macedonia, Skopje, $78 \mathrm{p}$.

CVETKOVIĆ, V., PRELEVIĆ, D., DOWNES, H., JOVANOVIĆ, M., VASELLI, O. \& PÉCSKAY, Z. (2004): Origin and geodynamic significance of Tertiary postcollisional basaltic magmatism in Serbia (central Balkan Peninsula).- Lithos 73, 161-186.

CVIJIĆ, J. (1906): Osnovi geografije i geologije Makedonije i Stare Srbije [Fundamentals for geography and geology of Macedonia and Ancient Serbia - in Serbian].- Belgrade. I-III, 1906-1911.

CVIJIĆ, J. (1924): Geomofologija [Geomorphology - in Serbian].- Belgrade I-II, 1924-1926. 
DENKOVSKI, GJ., IVANOV, T. \& DUMURDZANOV, N. (1983): Izveštaj za kompleksnite geološki istražuvanja na rudnata oblast Bučim-DamjanBorov Dol vo 1982 [Report for the complex geological exploration of the Bučim-Damjan-Borov Dol ore area in 1982 - in Macedonian].- Professional Fund of the Geological Survey of the Republic of Macedonia, Skopje, $87 \mathrm{p}$.

DENKOVSKI, N. \& BANDILOV, L. (1985): Izveštaj za kompleksnoto geološko istražuvanje na oblasta Bučim-Damjan-Borov Dol, lokalnost Cukarka [Report for the complex geological exploration of the BučimDamjan-Borov Dol ore area, Cukarka locality - in Macedonian].- Professional Fund of the Geoinstitute, Republic of Macedonia, Skopje, 62 p.

DEPAOLO, D.J. \& WASSERBURG, G.J. (1979): Petrogenetic mixing models and Nd-Sr isotopic patterns.- Geoch. Cosmoch. Acta, 43, 615-627.

DOWNES, H., SEGHEDI, I., SZAKACS, A., DOBOSI, G., JAMES, D.E., VASELLI, O., RIGBY, I.J., INGRAM, G. A., REX \& PÉCSKAY, Z. (1995): Petrology and geochemistry of late Tertiary/Quaternary mafic alkaline volcanism in Romania.- Lithos, 35, 65-81.

DUMURDŽANOV, N., RAKIČEVIĆ, T. \& PETKOVSKI, P. (1969): Tolkuvač za osnovnata geološka karta (BGM) na SFR Yugoslavija list Štip [Guide for the Basic Geological Map (BGM) of S.F.R. Yougoslavia sheet Stip - in Macedonian].- Geological Survey of the Republic Macedonia, Skopje, $61 \mathrm{p}$

DUMURDZANOV, N., SERAFIMOVSKI, T. \& BURCHFIEL, B.C. (2004): Evolution of the Neogene-Pleistocene basins of Macedonia: Geol. Soc. America Digital Map and Chart Series MC01, $20 \mathrm{p}$.

ECONOMOU-ELIOPOULOS, M. (2010): Platinum-group elements (PGE) in various geotectonic settings: opportunities and risks.- Hell. J. Geosc., 45, $65-82$.

ERMAKOV, N.P \& DOLGOV, Y.A. (1979): Termobarogeokhimiya [Thermobarogeochemistry - in Russian].- Nedra, Moscow, Russia, 270 p.

GERMAN, A., LANG, R., WERNER, W. \& FRIEDRICH, G. (1994): Zur Mineralogie und Geochemie der Erzgänge im Bergbaurevier FreiamtSexau, Mittlerer Schwarzwald.- In: STORCH, D.H. \& WERNER, W. (eds.): Die Erz- und Mineralgänge im alten Bergbaurevier "FreiamtSexau, Mittlerer Schwarzwald Abh. Geol. Landesamt Baden-Württemberg, 14, 119-155.

GRINENKO, A. V. \& GRINENKO, N.L. (1974): Geokhimiya izotopov sery [Geochemistry of sulfur isotopes - in Russian].- Publisher "Nauka", Moscow, Russia, $274 \mathrm{p}$.

GÜNTHER, D., VON QUADT, A., WIRZ, R., COUSIN, H. \& DIETRICH, V.J. (2001): Elemental analyses using laser ablation-inductively coupled plasma-mass spectrometry (LA-ICP-MS) of geological samples fusEd with $\mathrm{Li}_{2} \mathrm{~B} \mathrm{O}_{4}$ and calibrated without matrix-matched standards.- Microchim. Acta, 136, 101-107.

HALTER, W.E., BAIN, N., BECKER, K., HEINRICH, C.A., LANDTWING, M., VON QUADT, A., CLARK, A.H., SASSO, A.M., BISSIG, T. \& TOSDAL, R.M. (2004): From andesitic volcanism to the formation of a porphyry $\mathrm{Cu}-\mathrm{Au}$ mineralizing magma chamber: the Farallon Negro Volcanic Complex, northwestern Argentina.- J. Volc. and Geoth. Res., 136, 1-30.

HARKOVSKA, A., YANEV, Y. \& MARCHEV, P. (1989): General features of the Paleogene orogenic magmatism in Bulgaria.- Geol. Balc., 19, 37-72.

HEINRICH, C.A. \& NEUBAUER, F. (2002): $\mathrm{Cu}-\mathrm{Au}-\mathrm{Pb}-\mathrm{Zn}-\mathrm{Ag}$ metallogeny of the Alpine-Balkan-Carpathian-Dinaride geodynamic province.Min. Dep., 37, 533-540.

HILL, N.J., JENKIN, G.R.T., BOYCE, A.J., SANGSTER, C.J.S., CATTERALL, D.J., HOLWELL, D.A., NADEN, J. \& RICE, C.M. (2015): How the Neoproterozoic S-isotope record illuminates the genesis of vein gold systems: an example from the Dalradian Supergroup in Scotland.- In: JENKIN, G.R.T., LUSTY, P.A.J., MCDONALD, I., SMITH, M.P., BOYCE, A.J. \& WILKINSON, J.J. (eds.): Ore Deposits in an Evolving Earth. The Geological Society of London, Special Publication, 393, 213-248.

HOFMANN, B. \& EIKENBERG, J. (1991): The Krunkelbach uranium deposit, Schwarzwald, Germany. Correlation of radiometric ages, U-Pb, $\mathrm{U}-\mathrm{Xe}-\mathrm{Kr}, \mathrm{K}-\mathrm{Ar}, \mathrm{Th}-\mathrm{U}$ with mineralogical stages and fluid inclusions.Econ. Geol., 86, 1031-1049.

HRISTOV, S., KARAJOVANOVIK, M. \& STRAČKOV, M. (1973): List Kavadarci, Osnovna geološka karta 1:100 000 [Sheet Kavadarci, Basic Geological Map 1:100000 - in Macedonian].- Federal Geological Survey, Belgrade.

HRKOVIĆ, K. (1985): Strukturno-petrofizička-metelagonetska proučavanja rudnog polja Bučim [Structural-petrophysical-metallogenetic studies of the Bucim ore field - in Serbian].- Faculty of Mining and Geology, Belgrade, Serbia, $46 \mathrm{p}$

IVANOV, T. \& JAŠMAKOVSKI, B. (1970): Odredba i interpretacija na rudni primeroci od naođališteto Bučim Centralen del i Čukar [Determination and interpretation of ore polished sections from the Bučim ore deposit Central Part and Cukar - in Macedonian].- Professional Fund of Geological Survey - Skopje, $29 \mathrm{p}$.

IVANOV, T. (1982): Metalogenetski proučuvanja na oblasta Bučim-DamjanBorov Dol [Metallogenetic study of the Bučim-Damjan-Borov Dol ore area - in Macedonian].- Bučim Mine Professional Geological Survey Fund, Radoviš, Macedonia, $76 \mathrm{p}$.

JANKOVIĆ, S. \& PETKOVIĆ, M. (1974): Metallogeny and concepts of geotectonic development of the Yugoslavia.- In: Proceeding: Metallogeny and concepts of geotectonic development of the Yugoslavia, Dedicated to prof. dr. D. Milovanović, Faculty of Mining and Geology, Belgrade, Serbia, 369-394.

JANKOVIĆ, S. (1977): The copper deposits and geotectonic setting of the Tethyan Eurasian metallogenetic belt.- Min. Dep., 12/1, 37-47.

JANKOVIĆ, S. (1981): Mineralna ležišta - Geneza rudnih ležišta [Mineral ore deposits-Genesis of ore deposits - in Serbian].- Faculty of Mining and geology, Belgrade, Serbia, $529 \mathrm{p}$.

JANKOVIC, S., (1990): Ore deposit of Serbia.- Faculty of Mining and Geology, Belgrade, $765 \mathrm{p}$.

JANKOVIĆ, S. (1997): The Carpatho-Balkanides and adjacent area: a sector of the Tethyan Eurasian metallogenic belt.- Min. Dep., 32, 426-433.

JANKOVIĆ, S., SERAFIMOVSKI, T., JELENKOVIĆ, R. \& ČIFLIGANEC, V. (1997): Metallogeny of the Vardar Zone and Serbo-Macedonian Mass.Symposium-Annual Meeting, Proceeding, Dojran, 29-67.

JENSEN, M. L. (1959): Sulfur Isotopes and Hydrothermal Mineral Deposits.Econ. Geol., 54/3.

KARAMATA, S. (1974): Geohemijske, petrološke i metalogenetske provincije Kredno-Tercijarne starosti u delovima Balkanskog Poluostrva i Male Azije [Geochemical, petrological and metallogenetic provinces of Cretaceous-Tertiary age at parts of the Balkan Peninsula and Middle East - in Serbian].- SANU, Special Edition, vol. CDLXXV, Belgrade, Serbia, 55 p.

KARAMATA, S. \& LOVRIĆ, A. (1978): The age of metamorphic rocks of Brezovica and its importance for the explanation of ophiolite emplacement.- Bull. Acad, Serbe, Sci., 17, 1-9.

KARAMATA, S. \& DJORDJEVIĆ, P. (1980): Origin of the Upper Cretaceous and Tertiary magmas in the Eastern parts of the Yugoslavia.- Bull. Acad. Serb. des sci., et des arts. LXXII classe des Sci. et mathem., Belgrade, 20, 99-108.

KARAMATA, S. (1983): Koncentracija nekih mikroelemenata u Tercijarnim magmatitima istočnih delova Jugoslavije povezanih sa njihovom geotektonskom pozicijom [Concentration of some microelements in Tertiary magmatites of eastern part of Yugoslavia related to their geotectonic position - in Serbian].- Glas CCCXXXV SANU- Belgrade. Department of Natural and Matemathical sciences, 49, 39-54

KNEŽEVIĆ, V., STEINGER, R.H., DJORDJEVIĆ, P. \& KARAMATA, S. (1989): Precambrian contribution to the Tertiary granitic melts at the southern margin of the Panonian Basin. Symposium Precambrian granitoides.Abstracts. Geol. Survey of Finland Espoo, Helsinki, Spec., 8, 75 p.

KONONOVA, V.A., TERZIC, M. \& SVESHNIKOVA, E.B. (1989): Petrochemical series of alkali basalts in the Vardar Zone and Carpatho-Balkan arc.- Macedonian Academy of Sciences and Arts, 29-44.

KRIVTSOV, A.L. (1983): Geologicheskiye osnovy prognoza i razvedki medno - porfirovykh mestorozhdeniy [Gegological fundamentals of prognosis and exploration of copper porphyry deposits - in Russian].- Publisher "Nedra", Moscow, Russia, $254 \mathrm{p}$

LEHMANN, ST., BARCIKOWSKI, J., VON QUADT, A., GALLHOFER, D., PEYTCHEVA, I., HEINRICH, C.A. \& SERAFIMOVSKI, T. (2013): Geochronology, geochemistry and isotope tracing of the Oligocene magmatism of the Bučim-Damjan-Borov Dol ore district: Implications for timing, duration and source of the magmatism.- Lithos, 180/181, 216-233.

LIPPOLT, H.J. \& WERNER, O. (1994): Die genetische Aussage von BleiIsotopen-Verhältnissen in Bleiglanzen des Bergbaureviers Freiamt-Sexau, Mittlerer Schwarzwald.- In: STORCH, D.H. \& WERNER, W. (eds.): Die Erz-und Mineralgänge im alten Bergbaurevier "Freiamt-Sexau, Mittlerer Schwarzwald Abh. Geol. Landesamt Baden-Württemberg, 14, 191-205.

LÜDERS, V. (1994): Geochemische Untersuchungen an Gangartmineralen aus dem Bergbaurevier Freiamt-Sexau und dem Badenweiler-Quarzriff, Schwarzwald.- In: STORCH, D.H. \& WERNER, W. (eds.): Die Erz-und Mineralgänge im alten Bergbaurevier "Freiamt-Sexau, Mittlerer Schwarzwald Abh. Geol. Landesamt Baden-Württemberg, 14, 173-191.

MAJER, V. (1958): Trahi-andezit (delenit latit) iz Pilava i Šopura u Makedoniji [Trachy-andesite (Delenite latite) from Pilav and Sopur in Macedonia - in Croatian].- Yearbook of the Faculty of Philosophy, Skopje, 2/7, $23-32$.

MARCHEV, P., RAICHEVA, R., DOWNES, H., VASELLI, O., CHIARADIA, M. \& MORITZ, R. (2004): Compositional diversity of Eocene-Oligocene basaltic magmatismin the Eastern Rhodopes, SE Bulgaria: implications for genesis and tectonic setting.- Tectonophysics, 393, 301-328.

MISRA, K. (2000): Understanding Mineral Deposits.- Kluwer Academic Publishers, Dodrecht, Netherland, $845 \mathrm{p}$

MITCHELL, A.H.G. \& GARSON, M.S. (1981): Mineral deposits and global tectonic settings.- Academic Press, New York, $410 \mathrm{p}$.

MUDRINIĆ, C. \& PETKOVIĆ, M. (1974): Izotopni sastav sulfura u piritima iz rudnog polja Bučim [Sulfur isotope composition of pyrites from Bučim 
ore field - in Serbian].- Faculty of Mining and Geology, Belgrade, Serbia 22-31.

MÜLLER, D., ROCK, N.M.S. \& GROVES, D.I. (1992): Geochemical discrimination between shoshonitic and potassic volcanic-rocks in different tectonic settings-a pilot-study.- Min. Petrol., 46, 259-289.

MÜLLER, D. \& GROVES, D.I. (2000): Potassic igneous rocks and associated gold-copper mineralization.- Springer-Verlag Berlin-Heidelberg, 272 p.

NEVENIĆ, N. (1984): Izveštaj o rudno-mikroskopskim ispitivanjima primeraka iz Bunardžika, Bučim [Report from ore-microscopic study of samples from Bunardžik, Bučim - in Serbian].- Professional Fund Geoinstitute Belgrade, $14 \mathrm{p}$

OHMOTO, H. \& RYE, R.O. (1979): Isotopes of sulphur and carbon.- In: BARNES, H.L. (ed.): Geochemistry of Hydrothermal Ore Deposits, $2^{\text {nd }}$ Ed. John Wiley \& Sons, New York, 509-567.

OHMOTO, H. (1986): Stable Isotope geochemistry of ore deposits.- In: VALLEY, J.W., TAYLOR, H., P IR, O. \& NEIT, J.R. (eds.): Stable Isotopes in high temperature geological processes. Rev. Mineral, 16, 491-559.

OVTCHINIKOV, L. (1976): Istochniki rudnogo veshchestva endogennykh mestorozhdeniy i nadezhnost' kriteriyev ikh ustanovleniya [Ore sources of endogenous deposits and reliability criteria of their establishment - in Russian].- Proceedings of sources of ore deposits, Publ. Nauka, Moscow, $100-120$

PALINKAŠ, L. STRMIĆ PALINKAŠ, S., BERMANEC, V., SERAFIMOVSKI, T. \& VINCETIĆ, I. (2008): Fluid inclusion in quartz from the Bučim Cu-porphyry deposit, Eastern Macedonia.- In: SERAFIMOVSKI, T. (ed.): Proceedings of the National Congres of Macedonian Geologists Geologica Macedonia, Spec. No. 2, 193-199.

PAMIĆ, J. \& JURKOVIĆ, I. (1997): Alpine magmatic-metallogenic formations of the northwestern and central Dinarides.- Rud.-geol-naft. zb. Zagreb, 9, 1-9.

PAVIČEVIĆ, M. \& RAKIĆ, S. (1983): Proučavanje pojava zlata, srebra i drugih retkih elemenata u rudama Centralnog rudnog tela, Bučim [Study of occurence of gold, silver and other rare elements in ores from the Central ore body, Bučim - in Serbian].- Ulema, Belgrade, 202 p.

PAVLOVIĆ, M. (1939): Izveštaj o detaljnim geološkim istraživanjima lista Štip [Report for detailed geological exploration of the sheet Štip 1:100000 - in Serbian].- Annuals of Geological Institute, Kingdom Jugoslavia, Belgrade, $6,43 \mathrm{p}$

PEARCE, J.A. (1983): Role of the sub-continental lithosphere in magma genesis at active continental margins.- In: HAWKESWOTH, C.J. \& NORRY, M.J. (eds): Continetal Basalts and Mantle Xenoliths. Shiva, Nantwich, 230-249.

PEARCE, T.A., ALABASTER, T., SHELTON, A.W. \& SEARLE, M.P. (1981): The Oman ophiolite as a Cretaceous arc-basin complex: Evidence and implications.- Phil. Trans. of R. Soc., London A-300, 299-317.

PE-PIPER, G. \& PIPER, D.J.W. (2001): Late Cenozoic, post collisional Aegean igneous rocks: $\mathrm{Nd}, \mathrm{Pb}$ and $\mathrm{Sr}$ isotopic constraints on petrogenetic and tectonic models.- Geol. Mag., 138, 653-668.

PETKOVIĆ, M. (1966): Geohemijska prospekcija rudne oblasti DamjanBučim [Geochemical prospection in the Damjan-Bučim ore area-in Serbian].- Str. Faculty of Mining and Geology, Belgrade, Serbia, $34 \mathrm{p}$

PETKOVIĆ, M., ET AL. (1968): Geohemiska prospekcija rudne oblasti Damjan-Bučim i susednih oblasti [Geochemical prospection in the Damjan-Bučim ore area and its neighbouring area - in Serbian].- Str. Faculty of Mining and Geology, Belgrade, Serbia, $45 \mathrm{p}$.

PETRUNOV, R., DRAGOV, P, IGNATOV, G., HEYKOV, H., ILIEV, TS., VASSILEVA, N., TZATZOV, V., DJUNAKOV, S. \& DONCHEVA, K. (1992): Hydrothermal PGE-mineralization in the Elatsite porphyry-copper deposit (Sredna Gora metallogenic zone, Bulgaria).- Compt. Ren. Acad. Bulg. Sci, 45/4, 37-40.

PETRUNOV, R., SERAFIMOVSKI, T. \& DRAGOV, P. (2001): New finding of PGE-mineralisation in porphyry-copper environment-the Bučim deposit, Macedonia: preliminary microscope and microprobe data.- ABCDGEODE 2001 Workshop Vata Bai, Romania, 79, suppl. 2, 79-80.

PETUNIKOV, G. (1940): Berging Uber Eine interesuchungen auf kopferze in Macedonien.-- Montanistischen Rundschau Sonderabduck, 17.

PETUNIKOV, G. (1944): Kupfererzvorkommen bei Dorfe Butschim Kreis Štip in Macedonien Sonderabdisk aus "Mettal und Erz", Wien, 42 Jahr H 9/10.

PRELEVIĆ, D., FOLEY, S.F., ROMER, R.L., CVETKOVIĆ, V. \& DOWNES, H. (2005): Tertiary ultrapotassic volcanism in Serbia: constraints on petrogenesis and mantle source characteristics.- J. Petrol., 46, 14431487.

RAY, J.S., RAMESHA, R., PANDEA, K., TRIVEDI, J.R., SHUKLA, PN. \& PATEL, P.P. (2000): Isotope and rare earth element chemistry of carbonatite \pm alkaline complexes of Deccan volcanic province: implications to magmatic and alteration processes.- J. Asian Earth Sci., 18, 177-194.

RITTER, J. (1995): Genese der Mineralistation Herrmanngang im Albtalgranit, SE-Schwarzwald und Wechselwirkungen mit dem Nebengestein.Karls. Geoch. Hefte, 8, 1-132.
ROEDDER, E. (1984): Fluid inclusions.- Reviews in Mineralogy, Geological Society of United States of America, 12, $644 \mathrm{p}$.

ROLLINSON, H. (1992): Using Geochemistry Data: evaluation, presentation, interpretation.- Prentice Hall, an Imprint of Pearson Education, Harlow, England, $352 \mathrm{p}$

RYE, R., HALL, W. \& OHMOTO, H. (1974): Carbon, Hydrogen, Oxygen and Sulphur isotope Study of the Lead-Silver-Zinc Deposit, Southern California--Econ. Geol., 69, 468-481.

SAKAI, H. (1968): Isotopic Properties of Sulfur Compound in Hydrothermal Processes.- Geoh. J., 2, 29-49.

SCHEFER, S., CVETKOVIC, FÜGENSCHUH, B., KOUNOV, A., OVTCHAROVA, M., SCHALTEGGER, U. \& SCHMID, S.M. (2011): Cenozoic granitoids in the Dinarides of southern Serbia: age of intrusion, isotope geochemistry, exhumation history and significance for the geodynamic evolution of the Balkan Peninsula.- Int. J. Earth Sci., 100, 1181-1206

SCHMID, S.M., BERNOULLI, D., FÜGENSCHUH, B., KOUNOV, A., OBERHÄNSLI, R., SCHEFER, S., VAN HINSBERGEN, D. \& USTASZEWSKI, K. (2013): Similarities and differences between Alps Carpathians. Dinarides-Hellenides and Anatolides-Taurides.- EGU, 15, 3525 .

SCHWINN, G., WAGNER, T., BAATARTSOGT, B. \& MARKL, G. (2006): Quantification of mixing processes in ore-forming hydrothermal systems by combination of stable isotope and fluid inclusion analyses.- Geoch. Cosm. Acta, 70, 965-982.

SERAFIMOVSKI, T. (1990): Metalogenija na zonata Lece-Halkidiki [Metallogeny of the Lece-Chalkidiki zone - in Macedonian].- Ph.D. thesis, Faculty of Mining and Geology, Stip, $390 \mathrm{p}$

SERAFIMOVSKI, T., MANKOV, S. \& ČIFLIGANEC, V. (1990): Bizmuthselenium mineralization within copper deposit Bučim-Radovis.- $12^{\text {th }}$ Congress of Geologists of Yugoslavia, Ohrid, 3, 73-85.

SERAFIMOVSKI, T., CIFLIGANEC, V. \& MANKOV, S. (1992): Morfologija na zlatoto prisutno vo porfirskoto naođalište na bakar Bučim Istočna Makedonija [Morphology of gold present in the Bučim porphyry copper deposit Eastern Macedonia - in Macedonian].- 24 ${ }^{\text {th }}$ October Counceling of Miners and Metalurgists, Bor, Serbia, 52-55.

SERAFIMOVSKI, T. (1993): Structural metallogenetic characteristics of the Lece-Chakidiki zone: Types of Mineral Deposits and Distribution.- Special Edition of RGF Stip, 2, 328 p.

SERAFIMOVSKI, T. \& BOEV, B. (1996): Metallogeny of the Kratovo-Zletovo volcano-intrusive complex.- Terranes of Serbia (356), 347-352.

SERAFIMOVSKI, T., ČIFLIGANEC, V., JANKOVIĆ, S. \& BOEV, B. (1996): Genetic Model of the Bučim Porphyry Copper Deposit, R. Macedonia.- In: Proceedings of the Annual Meeting, UNESCO-IGCP Project 356, Sofia, 1, 63-75.

SERAFIMOVSKI, T., JELENKOVIĆ, R. \& ALEXANDROV, M. (2000): Geodynamics and evolution of the Alpine ore deposits in southern parts of the Carpatho-Balkanides.- Abstract Book, ABCD-GEODE 2000 Workshop, Borovets, Bulgaria, 31.

SERAFIMOVSKI, T. \& TASEV, G. (2005): Sulfur isotope composition of some polymetallic deposits in the Republic of Macedonia.-Geol. Maced., $19 / 1,1-11$.

SERAFIMOVSKI, T., TASEV, G. \& LAZAROV, P. (2006): Au-Ag-Te-Bi-Se minerals associated with porphyry copper mineralization in the Bučim copper mine, R. Macedonia.- Au-Ag-Te-Se deposits IGCP-486, Field Workshop, Izmir, Turkey, 154-158.

SERAFIMOVSKI, T., STEFANOVA, V. \& VOLKOV, A.V. (2010): Dwarf copper-gold porphyry deposits of the Bučim-Damjan-Borov Dol ore district, Republic of Macedonia (FYROM).- Geol. Ore Dep., 52, 179-195.

SERAFIMOVSKI, T., BLAŽEV, K., TASEV, G. \& POCKOV, K. (2013): AuPd bearing pyrites and chalcopyrites from the Bučim porphyry copper deposit, Eastern Macedonia.- Proceedings of the $12^{\text {th }}$ Biennial SGA Meeting, Uppsala, Sweden, 2, 876-879.

SHELTON, K.L. \& RYE, D.M. (1982): Sulfur isotope compositions of ore from Mines Gaspe, Quebec: An example of sulfate-sulfide isotopic disequilibria in ore-forming fluids with applications to other porphyry-type deposits.- Econ. Geol. 77, 1688-1709.

SMIRNOV, V.L. (1976): Evolyutsiya istochnikov endogennykh rudnykh mestorozhdeniy $\mathrm{v}$ techeniye istorii Zemli [Evolution of sources of endogoneous ore deposits during the history of Earth - in Russian].- Proceedings of sources of ore deposits, Publ. "Nedra", Moscow, 8-11.

SOTNIKOV, V.I., BERZINA, A.P. \& JAMSRAN, M. (1985): Med' - rudnyye formatsii v Mongol'skoy Narodnoy Respublike [Copper ore formations of Mongolian People's Republic - in Russian].- Nauka, Novosibirsk, 225 p.

STERNER, S.M., HALL, D.L. \& BODNAR, R.J. (1988): Synthetic fluid inclusions. V. Solubility relations in the system $\mathrm{NaCl}-\mathrm{KCl}-\mathrm{H}_{2} \mathrm{O}$ under vapor saturated conditions.- Geoch. Cosm. Acta, 52, 989-1005.

STOJANOV, R. \& SERAFIMOVSKI, T. (1990): Osnovni karakteristiki na Tercierniot magmatizam vo oblasta Bučim-Borov Dol [Basic features of the Tertiary magmatism in the Bučim-Borov Dol area - in Macedonian].$12^{\text {th }}$ Congress of geologists of Yugoslavia, Ohrid, 2, 404-423. 
STOJANOV, R. \& BOEV, B. (1993): Oligocensko-Neogeniot magmatizam vo oblasta na Bučimskiot blok [Oliocene-Neogene magmatism at the Bučim Blok area - in Macedonian].- In: Study for potentiality of the Bučim ore field in regards to discovery of new copper and gold reserves. Professional Fund of the Bučim mine geological survey, PRMB Buchim-Radoviš, $93 \mathrm{p}$.

STOLZ, A.J., JOCHUM, K.P, SPETTEL, B. \& HOFMANN, A.W. (1996): Fluid- and melt-related enrichment in the subarc mantle: evidence from $\mathrm{Nb}$ /Ta variations in island arc basalts.- Geology, 24/7, 587-590.

STRASHIMIROV, S. \& KOVATCHEV, V. (1992): Temperatura na formirane na medni nakhodishta ot zona - danni ot prouchvaniya Srednogorie fluidni vklyuchvane $\mathrm{v}$ minerali [Temperature of formation in copper deposits from the Srednogorie zone-data from fluid inclusion studies in minerals - in Bulgarian with English abstract].- Rev. Bulg. Geol. Soc., 53/2, 1-12.

STRASHIMIROV, STR., SERAFIMOVSKI, T. \& KOVACHEV, V. (1996): Temperatures of the Ore-forming Processes in the Bučim Porphyry Copper Deposit (Macedonia): Data from Fluid Inclusion Studies.- Geol. Ore Dep., Moscow, 38/4, 373-377.

SUN, S.S. \& MCDONOUGH, W.F., (1989): Chemical and isotopic systematics of oceanic basalts: implications for mantle composition and processes.- Geol. Soc., London, Special Publications 42, 313-345.

TAYLOR, H.P. (1987): Comparison of hydrothermal systems in layered gabbros and granites, and the origin of $l o w-\delta^{18} \mathrm{O}$ magmas.- In: Magmatic processes: physicochemical principles. Geoch. Soc. Special Publication $1,337-357$

TAYLOR, H.P. (1997): Oxygen and hydrogen isotope relationships in hydrothermal mineral deposits.- In: BARNES, H.L. (ed.): Geochemistry of hydrothermal ore deposits, $3^{\text {rd }}$ Ed. New York, Wiley-Interscience, 229-302.

TARKIAN, M., ELIOPOULOS, D.G. \& ECONOMOU-ELIOPOULOS, M. (1991): Mineralogy of precious metals in the Skouries porphyry copper deposit, N. Greece.- Neu. Jahr. Min. Abh., 12, 529-537.

TASEV, G. (2003): Polimetalnite mineralizacii povrzani so Tercierniot magmatizam vo Republika Makedonija [The polymetallic mineralizations related with Tertiary magmatism in the Republic of Macedonia - in Macedonian].- Masters thesis, Faculty of Mining and Geology, University "Sts. Cyril and Methodius", Štip, 176 p.
TASEV, G., SERAFIMOVSKI, T. \& LAZAROV, P. (2005): New K-Ar, ${ }^{87} \mathrm{Sr} /{ }^{86} \mathrm{Sr}, \mathrm{REE}$, and XRF data for Tertiary volcanic rocks in the SasaToranica ore district, Macedonia.- In: JINGWEN MAO \& FRANK P. BIERLEIN (eds.): Mineral Deposit Research: Meeting the Global Challenge, $8^{\text {th }}$ SGA Biennial Meeting, Beijing, China, 837-840.

TOMSON, I.N., SERAFIMOVSKI, T. \& KOCHNEVA, N.T. (1998): Cenozoic Metallogeny of Eastern Macedonia.- Geol. Ore Dep., 40/4, 195-204

VANKO, D.A., BODNAR, R.J. \& STERNER, S.M. (1988): Synthetic fluid inclusions. VIII. Vapor-saturated halite solubility in part of the system $\mathrm{NaCl}-\mathrm{CaCl}_{2}-\mathrm{H}_{2} \mathrm{O}$, with application to fluid inclusions from oceanic hydrothermal systems.- Geoch. Cosm. Acta, 52, 2451-2456.

VOLKOV, A., SERAFIMOVSKI, T., KOCHNEVA, N.T., TOMSON, I.N. \& TASEV, G. (2006): The Alshar Epithermal Au-As-Sb-Tl Deposit, Southern Macedonia.- Geol. Ore Dep., 48/3, 175-192.

VOLKOV, A., SERAFIMOVSKI, T. \& STEFANOVA, V. (2010): Formation Mechanism of Dwarfish Cu-Au Porphyry Deposits of Macedonia.- Dokl. Earth Sci., 431/5, 649-655.

WEBER, A. (1997): Geochemische Untersuchungen zur Genese der BleiZink-Lagerstätte am Schauinsland im Schwarzwald [Geochemical studies on the genesis of lead-zinc deposit at the Schauinsland in the Black Forest - in German].-Unpublished diploma thesis, University of Tübingen, $82 \mathrm{p}$.

WERNER, W., SCHLAEGEL-BLAUT, P. \& RIEKEN, R. (1990): Verbreitung und Ausbildung von Wolframmineralisationen im Kristallin des Schwarzwaldes [Dissemination and training of tungsten mineralization in the crystalline of the Black Forest - in German].- Jh. Geol. Landesamt Baden-Württemberg, 32, 17-61.

WERNER, W., FRANZKE, H.-J. \& LÜDERS, V. (2000): Zur Genese der Zink-Blei-Lagerstätte Schauinsland [On the genesis of the zinc-lead deposit Schauinsland - in German].- Erzmetall, 53, 273-285.

YANEV, Y., BOEV, B., DOGLIONI, C., INNOCENTI, F., MANETTI, P, PECSKAY, Z., TONARINI, S. \& D’ORAZIO, M. (2008): Late Miocene to Pleistocene potassic volcanism in the Republic of Macedonia.- Min. Petr., 94, 45-60.

ZARIĆ, P. (1974): Studija genetsko-paragenetskih karakteristika Cu mineralizacije u Bučimu sa pregledom mineralizacionim fazama tog ciklusa [Study of genetic-paragenetic features of Cu-mineralization Bucim with a review of mineralization stages of that cycle - in Serbian].- Professional fund, Bučim mine, $63 \mathrm{p}$. 